Columbia Law School

Scholarship Archive

1997

\title{
Private Ownership and Corporate Performance: Some Lessons from Transition Economies
}

\author{
Roman Frydman \\ roman.frydman@nyu.edu \\ Cheryl W. Gray \\ author55598@ssrn.com \\ Marek P. Hessel \\ hessel@fordham.edu \\ Andrzej Rapaczynski \\ Columbia Law School, ar5@columbia.edu
}

Follow this and additional works at: https://scholarship.law.columbia.edu/faculty_scholarship

Part of the Business Organizations Law Commons, European Law Commons, and the Law and Economics Commons

\section{Recommended Citation}

Roman Frydman, Cheryl W. Gray, Marek P. Hessel \& Andrzej Rapaczynski, Private Ownership and Corporate Performance: Some Lessons from Transition Economies, WORLD BANK POLICY RESEARCH WORKING PAPER No. WPS1830 (1997).

Available at: https://scholarship.law.columbia.edu/faculty_scholarship/1152

This Working Paper is brought to you for free and open access by the Faculty Publications at Scholarship Archive. It has been accepted for inclusion in Faculty Scholarship by an authorized administrator of Scholarship Archive. For more information, please contact scholarshiparchive@law.columbia.edu. 


\title{
PRIVATE OWNERSHIP AND CORPORATE PERFORMANCE: SOME LESSONS FROM TRANSITION ECONOMIES ${ }^{1}$
}

\author{
Roman Frydman, ${ }^{2}$ Cheryl Gray, ${ }^{3}$ Marek Hessel, ${ }^{4}$ Andrzej Rapaczynski ${ }^{5}$ \\ June 1997
}

\footnotetext{
${ }^{1}$ The authors are grateful to the CEU Foundation, the Open Society Institute and the World Bank for supporting research on this paper. CV Starr Center for Applied Economics at New York University has provided this paper. thank Sarbajit Sinha for computer support in the initial stages of research.

${ }^{2}$ Department of Economics, New York University, and CEU Privatization Project

${ }^{3}$ The World Bank

${ }^{4}$ Graduate School of Business, Fordham University, and CEU Privatization Project

${ }^{5}$ Columbia University School of Law and CEU Privatization Project
} additional support for Roman Frydman's research. None of these institution are responsible for opinions expressed in

The authors would like to thank Joel Turkewitz for his contributions to the design and implementation of the survey instrument, and Mihaela Popescu for her extraordinary assistance in the analysis of the data. The authors also 


\begin{abstract}
This paper, based on a large sample of mid-sized firms in the Czech Republic, Hungary and Poland, compares the performance of privatized and state firms in the environment of the postcommunist transition. It provides strong evidence that private ownership, except for worker ownership, dramatically improves corporate performance. We find no evidence of any "privatization shock" which was supposed to afflict the behavior of the firms undergoing rapid ownership changes; we observe instead a severe shock of marketization, which affects both state and privatized firms, but to which private ownership provides a powerful antidote. We also find that the impact of private ownership is the strongest in enhancing a firm's ability to generate revenues -- an area in which entrepreneurship seems to be required. Ownership also affects a firm's ability to remove the rather obvious cost inefficiencies inherited from the past, but this effect is less pronounced, with both state and privatized firms engaging in significant amounts of cost restructuring. Most importantly, we find that privatized firms generate significant employment gains relative to state firms. Since it is its superior revenue-generating capability -rather than cost-cutting competence -- that allows a firm to sustain or expand employment, privatization turns out to be the dominant employment strategy in transition. We also discuss the performance differences among various private owners, and several of our findings in this area run contrary to widely held beliefs concerning the effects of managerial ownership and the role of privatization funds and foreign investors.
\end{abstract}

JEL Classification: P10, P12, P17. Keywords: ownership; privatization; performance; transition. 


\section{INTRODUCTION}

This paper is part of a larger study which deals, on different levels, with two issues: the impact of ownership on corporate performance in the environment of the postcommunist transition, and the more general role of ownership in a market economy. What connects the two is the special significance of the transition environment for the study of the importance of private ownership. This environment, because of its far-from-equilibrium characteristics, offers a unique testing ground for a number of hypotheses concerning the more universal economic significance of private ownership.

In more stable market economies, the impact of ownership on performance is more difficult to test. As Demsetz and Lehn (1985) point out, a firm's ownerships structure is itself subject to market pressures, so that in the long-run each firm that is capable of surviving competition will end up with an essentially close to optimal ownership structure. As a result, the impact of ownership on performance will remain largely unobservable in any society in which this process has been operating for some time. To be sure, state ownership is much less subject than private ownership to the operation of this "market for ownership structure." Nevertheless, the state may also be under pressure to stay out of areas in which the performance of state-owned firms is most manifestly inadequate (and the most difficult to legitimize), and confine itself to those in which access to large amounts of capital (which the state can provide or guarantee) is relatively important, where competition is less demanding, and where alternative governance arrangements may to some extent substitute for monitoring by owners.

Furthermore, the presence of a set of institutionalized routines and governance arrangements may partly compensate, at least in the short term, for the attenuated presence of the owners of capital in some firms, and thus obscure the long-term effects of the ownership itself. The most important characteristics of firms in which such compensatory arrangements can to a considerable extent substitute for private ownership are size and maturity. If a state firm operates in an area in which entry is costly, and technological change is slow and relatively predictable, and if the firm has a well established product and market, competent management should permit it to preserve its position and profitability, allowing it to perform at levels not so manifestly inferior to private firms as to create serious legitimation problems. Car manufacturers like Renault, state telecom companies prior to the recent technological revolution, as well as state railroads and airlines could for a while perform at levels not so manifestly inferior to private firms as to create serious pressure for denationalization. Even then, state firms usually deteriorate over time due primarily to political depredations and special-interest demands that state bureaucrats find very difficult to resist. Absent such political pressures, however, state enterprises in some areas may hold their own and withstand a certain amount of competition. ${ }^{1}$

\footnotetext{
${ }^{1}$ The fact that state firms tend to operate in more capital intensive and less competitive sectors often increases the possibility of waste and political mismanagement. The creation of a competitive environment can then sometimes improve performance as much as privatization. See Vickers and Yarrow (1988).
} 
When ownership is likely to matter most and governance substitutes are likely to be much less effective, is when a firm's environment is characterized by a high degree of uncertainty and the conduct of business calls for the exercise of entrepreneurship. If technological innovation, general economic dislocation, or other exogenous shocks produce a need for rapid reorientation and risk taking, state ownership -- we suggest -- will be particularly ineffective, even if state firms operate in a competitive environment. ${ }^{2}$ The postcommunist transition environment, ripe with such shocks and characterized by far-from-equilibrium conditions, offers a unique testing ground for a number of hypotheses concerning the role of ownership in corporate behavior and performance. The following factors are particularly relevant in this respect:

1. The transition economies are characterized by a very large number of state and privatized firms in all areas of economic activity which start and operate in essentially similar conditions. This allows meaningful performance comparisons between state and private firms, as well as comparisons among various forms of private ownership,

2. More generally, the environment of the postcommunist transition contains a wide variety of ownership forms in the early stages of their evolution, with many probably dysfunctional forms of ownership present and the distribution of the various forms largely unrelated to their effectiveness for the particular type of business. This "far from equilibrium" condition makes it possible to examine the relative effectiveness of various forms of ownership before the less appropriate ones are weeded out.

3. Many of the mechanisms that attenuate -- and perhaps even substitute for -- the role of owners in mature economies are absent from the transition environment. Many firms are still shielded from external competition. Markets for managerial talent are very imperfect. ${ }^{3}$ Securities markets are in their infancy, and the degree to which they exercise any disciplining effect on management is still quite negligible. Corporate governance institutions, such as boards of directors, are still largely ineffective in substituting for direct monitoring by owners.

\footnotetext{
2 The results of our empirical work comparing the different ways in which state and privatized firms respond to competitive pressures will be presented in a separate paper. That competition in general, which only forces firms to do no worse than others, cannot substitute for ownership is argued in Frydman, Phelps, Rapaczynski, and Shleifer (1993)

3 The results of our study relating to managerial turnover and its causes, attitudes of managers and business strategies will be presented in a separate paper.
} 
4. Not surprisingly, therefore, ownership tends to be extremely concentrated in most Central and East European firms. ${ }^{4}$ Owners, who cannot afford to rely on other institutions and arrangements designed to monitor and discipline managerial performance, have both the power and incentives to exercise their rights. Thus, although the separation of ownership and management is common in the region, agency problems are likely to be tempered by the direct involvement of owners in many important decisions and day-to-day monitoring.

5. Finally, the environment of transition is characterized by a high degree of uncertainty and deep institutional change. Under these conditions, standard rules-driven behavior brings relatively meager competitive advantages. Success calls for spontaneity and innovation that can only be provided by the owner - indeed, not just any owner, but a private owner who is actively engaged in the running of the business.

If, therefore, different types of owners differ in their ability to improve their firms' performance, the environment of Central and Eastern Europe should magnify such effects and allow for their more accurate measurement and analysis.

\section{METHODOLOGY}

\section{Evaluating the impact of ownership}

There are two ways in which the relation between ownership and performance can be evaluated. The first is to compare pre- and post-privatization performance of selected privatized firms. Although intuitively appealing, this "historical" approach can suffer from the difficulty of sorting out a potential variety of causal factors. Pre- vs. post-privatization comparisons are more meaningful if they involve privatization programs through which significant numbers of state companies are transferred to the private sector. Such programs, however, usually come as parts of broader shifts in economic policies, often including, in addition to privatization, such changes as tighter financial discipline and a reduction in subsidies. As a result, it is difficult if not impossible to separate the effect of new ownership from the impact of the new policies. ${ }^{5}$ Moreover, traditional privatizations frequently involve significant injections of funds into the firms to be privatized and are usually preceded by extensive preparations during which management and organizational structures are revamped. ${ }^{6}$ The impact of these preparations may well account for

\footnotetext{
${ }^{4}$ Even in the Czech Republic the initial fears of widely dispersed holdings did not materialize and more than half of the voucher points distributed in the mass privatization program ended up with a handful of investment funds. See Frydman, Rapaczynski, and Turkewitz (1997) and Coffee (1996).

${ }^{5}$ This is also true in transition economies, where, as a result of variety of policy changes, restructuring of operations is common to privatized and state firms alike and thus cannot be attributed to ownership changes alone.

${ }^{6}$ British Steel, for example, is reported to have reduced its employment by $40 \%$ prior to privatization while keeping revenues constant; British Airways reduced its labor force by the same percentage, while actually increasing the number of flights. Djankov and Pohl (1977).
} 
some or all post-privatization improvements and cloud the impact of ownership change on 
company performance. ${ }^{7}$

7 Among the "historical" studies using privatized firms in predominantly market economies, the most important is 
Megginson et al. (1994), who compare the pre- and post-privatization performance of 61 firms in 18 countries and find that privatization increases profitability, output per employee, investment, and employment, as well as leading to lower leverage and higher dividend payouts. But the study does not control for changes in the economic environment or most forms of preprivatization restructuring. Moreover, although the authors try to reject the possibility that the improvements they noted were a result of significant injections of funds into the privatized companies, the rejection is based on a lack of reports of such injections in a few Western newspapers, and as such may not be overly reliable. Most of the remaining pre-1989 literature, predominantly based on small samples and lacking statistical significance, is listed and classified in Boardman and Vining (1989). An earlier review, together with an argument that private ownership is more efficient, may be found in De Alessi (1980). Among more recent studies, Caves (1990) surveys the impact of British privatization policies of the 1980; in a casetype study, Galal et al. (1994) examine the pre- and post-privatization performance of 12 firms in developing countries.

Most of the literature on the postcommunist transition and enterprise restructuring also follows the historical approach and is by now very large. Frydman and Rapaczynski (1994) provide references to the initial discussions which focused on the merits and demerits of different privatization programs. The first performance-focused studies of firms in transition dealt with so-called "small" privatization" (i.e., privatization of shops and other small establishments), which raises different issues from those discussed here. See Earle, Frydman, Rapaczynski, and Turkewitz (1994). Performance-focused studies of "large" privatization tend to concentrate on individual countries, particular owners, or specific problems, and usually involved comparisons of pre- vs. post-privatization performance. Some works of interest in the context of this paper are: Pinto, Belka and Krajewski (1993) and Pinto and van Wijnbergen (1994) (on the restructuring of state enterprises in Poland); Blanchard, Commander and Coricelli (1994) (on unemployment and restructuring in Eastern Europe); Djankov and Pohl (1997) (on restructuring of large firms in Slovakia); Balcerowicz, Gray and Hashi (1997) (on employment and output downsizing in the 200 largest manufacturing firms in the Czech Republic, Hungary, and Poland); Earle and Estrin (1996) (on employee ownership in transition); Claessens, Djankov and Pohl (1997b) (on the governance performance of Czech investment funds). Russian privatization, with its fairly unique problems, also produced a large number of studies: Lieberman and Nellis (1994) contains a number of essays on the restructuring of privatized firms. 
The second approach to evaluating the relation between ownership and performance focuses on comparing the performance of state and private firms operating under reasonably identical conditions: at the same time, in the same markets, within the same environment. This "synchronic" approach confronts its own difficulties. In order to capture the effect of ownership cleanly, a study must assure the absence of a selection bias. Such a bias might occur, for example, if state ownership was introduced in the first place to shore up firms that could not compete in the market (so that state firms were handicapped from the beginning). Or, if one wants to avoid this problem by comparing the performance of privatized (rather than originally private) firms to that of state companies, selection bias may occur if better firms were chosen for privatization. ${ }^{8}$

\footnotetext{
8 The most important "synchronic" study of performance of state, private and mixed enterprises in market economies is Boardman and Vining (1989), who compare the performance of the largest 500 non-US industrial corporations and find that private firms perform better along several dimensions than both state-owned and mixed firms, and that mixed firms do no better, and often worse, than state-owned companies. Although the Boardman and Vining control for sectoral and country influences, such controls are insufficient to exclude the selection bias hypothesis. Among the still rare synchronic comparisons of state and privatized firms in transition economies, the most important is the study by Pohl $e t$ al. (1997), who examine the performance of a large number of state and privatized firms in seven transition economies between 1992 and 1995. The study by Pohl et al, which appeared as this paper was going to print, begins to build a very powerful case in favor of the effectiveness of privatization. But the study fails to deal with the possibility of selection bias and is thus potentially open to the objection that the superior performance of privatized firms it reports may be due to factors other than the ownership itself.
} 
A reliable study of the effects of ownership on performance must combine the two approaches, comparing state and private firms operating at the same time, but using historical data, in addition to the synchronic comparisons, to eliminate the possibility of selection bias. This is the route we follow in this paper. We focus on comparisons of performance between state and privatized firms, leaving out the issue of the differences between either of these types of companies and new private firms. ${ }^{9}$ To establish that pre-privatization selection bias does not affect post-privatization results, we evaluate the pre-privatization performance of privatized firms relative to state firms and show that, originally, they did not differ significantly from each other (see part 5 below). ${ }^{10}$ To establish the later effect of ownership changes, we evaluate the postprivatization performance of privatized firms, again relative to state firms.

Based on these comparisons, we offer strong empirical evidence that private ownership, except for worker ownership, dramatically improves the most essential aspects of corporate performance in the countries undergoing the postcommunist transition. We find no evidence of any "privatization shock" afflicting the behavior of the firms undergoing rapid ownership changes; we observe instead a severe shock of marketization, which affects both state and privatized firms, but to which private ownership provides a powerful antidote. Moreover, the effect of privatization is the strongest where entrepreneurial acumen matters most -- it is the ability to stem revenue losses and often generate revenue increases that most strongly distinguishes privatized from state firms. Ownership also affects a firm's ability to remove rather obvious cost inefficiencies inherited from the past, but this is less pronounced, with both state and privatized firms engaging in significant cost restructuring. Most importantly, we find that privatized firms are also more successful at moderating employment losses. Since it is the revenue-creating capability -- rather than cost-cutting restructuring -- that allows a firm to grow, privatization turns out to be the dominant employment strategy in transition.

${ }^{9}$ Although startup firms are clearly the most dynamic and entrepreneurial businesses in Central and Eastern Europe, they are usually quite small and operate against very different background conditions (the most important of which is the absence of the pervasive inheritance from the socialist past), so that comparisons to both state and privatized firms raise extremely difficult methodological problems.

${ }^{10}$ Moreover, the overwhelming majority of Central and East European privatizations (and in nearly all cases of medium-sized companies we examine in this study) privatization was not preceded by any special preparations or other preprivatization restructuring that would further distinguish the privatized firms from their state-owned counterparts. 
The paper is organized as follows: the remainder of this section describes the sample firms, discusses the performance measures used in the analysis, and presents the two equations we use throughout the paper. The first equation allows us to estimate the general impact of privatization across all types of private owners, which we examine in Section 3. The second equation allows us to evaluate the performance differences among various private owners, which we discuss in Section 4. We complete our analysis in Section 5, where we evaluate the pre-privatization performance of privatized firms relative to state firms and reject the possibility that selection bias or moral hazard effects might affect our results. The final section contains concluding remarks and previews the remaining areas of our study. The supplement provides the regression statistics (Appendix A) and a detailed sample description (Appendix B.)

\section{The sample}

This paper analyzes performance implications of privatization of mid-sized firms in the Czech Republic, Hungary and Poland over the initial period of transition, from 1990 to mid-1994. These firms were part of a sample of over 500 mid-size firms, employing between 100 and 1,500 persons; the median 1993 employment in the sample is about 360 full-time employees, and the median 1993 sales are just short of US\$ 6 million. The size restriction brings into focus the region's more vibrant and dynamic manufacturing sector, which retains a lion's share of output and employment in transition economies. Its performance has significant implications for economic stability, budgetary policies, and political developments in the region; the ability of these firms to cope with the new environment is of vital importance to the transition process. The size restriction also leaves out the industrial "dinosaurs" of the communist era, the privatization of which raises special political and social problems.

The sub-sample used in this paper includes only state and privatized firms (i.e., it excludes firms which were never state-owned.) By a state firm we mean a firm in which private parties do not have a blocking power: its legal form may be that of a non-corporatized state enterprise, a corporatized state enterprise, or a privatized firm in which the combined shareholdings of private owners fall short of blocking power. ${ }^{11}$ By a privatized firm we mean an enterprise (partially or

\footnotetext{
${ }^{11}$ We consider private parties to have blocking power if they control the percentage of votes formally sufficient to block major decisions at the general shareholder meeting. If this is the case, we classify the firm as non-state even if the state
} 


\section{totally) privatized through a privatization of a predecessor state-owned company (or its part) in which the combined holdings of private parties give them a blocking power. ${ }^{12}$}

retains majority holdings, the situation arising in $15 \%$ of the privatized firms in our sample. Although the blocking power requirement is different from majority holding, the high concentration of holdings in our sample makes the difference academic. (For the identity of the largest owners and their holdings in the privatized firms in the sample, see Table B.2, Appendix B.)

12 However, we have excluded from our sample all firms privatized through leasing. (There were 25 such firms out of 506 in our sample, with 11 providing data complete enough to evaluate their performance.) The nature of leasing in Poland and ESOPs in Hungary made it difficult for us to categorize unambiguously the leased firms according to their ownership, especially when they were not employee-owned. Still, the inclusion of those firms produces no significant changes in the results reported in this paper. 
To allow for analysis of post-privatization performance, we limit our sample to firms privatized in 1990, 1991 and 1992 only $^{13}$. The number of these firms used in the analysis varies slightly with the particular aspect of performance under examination, as not all firms provided data complete enough to meaningfully track their showing; ${ }^{14}$ in general, however, the sample includes about 190 firms. These firms are split about evenly between privatized and state companies; $35 \%$ of them are in the Czech Republic, 39\% in Hungary, and 26\% in Poland. They operate both in consumer goods (food and beverages, clothing, and furniture) and in industrial goods sectors (non-ferrous minerals, chemicals, textiles and leather), with roughly $58 \%$ of privatized firms and $48 \%$ of state firms in consumer goods sectors. (Distributions of sample firms by type, country and industrial sector are provided in Appendix B.)

All privatized firms in the sample have highly concentrated ownership: except for privatization funds, the average holdings of private parties in the position of the largest owner are majority holdings. ${ }^{15}$ The sole exception - privatization funds - is due to legal limitations. All of these institutions in our sample are investment funds in the Czech Republic, whose holdings in individual firms were legally capped at 20 percent. Even then, the combined holdings of different investment funds in a single firm typically add up to a majority.

This degree of concentration not only identifies the typical ownership structure as a dominant-owner arrangement, but also comes sufficiently close to a single-owner structure to allow us to ignore the other owners and identify the firm's ownership type with that of the largest shareholder. ${ }^{16}$ The most frequent among those owners in our sample are foreign investors (the largest shareholders in nearly $30 \%$ of privatized firms), followed by managerial or non-managerial employees (over $20 \%$ of privatized firms.) (See Appendix B)

\section{Performance measures}

We focus much of our attention on the revenue performance of a firm. Economists tend to think of profit as the measure of performance that best captures both the creativity (the revenue side) and the discipline (the cost side) required for survival in a market economy. In the long run

13 There were no annual post-privatization data for sample firms privatized in 1993 or early 1994.

14 We have no reason to believe that the incompleteness of data for certain firms (which relates primarily to lack availability or an obvious misunderstanding of the meaning of certain questions, such as those concerning the initial period for which data were to have been provided) introduces any systematic bias "in favor" or "against" any group of firms.

${ }^{15}$ The ownership distribution in our sample is not fully representative of the population of firms from which it was drawn, since the sample was stratified by the type of owner. Thus, if certain owners (such as foreign trade investors) tend to acquire larger stakes, stratification may bias the sample in favor of greater concentration. Similarly, if a firm was chosen in order to include a certain type of owners, the firm so chosen would probably be one in which that owner was represented at a significant enough level (thus adding to an overall bias in favor of greater concentration).

${ }^{16}$ State as the largest owner provides an important exception. As we discuss later in the paper, in privatized firms when the state remains the largest owner, the second owner (or, more generally, the largest private owners) is likely to be important. 
this is true. But in the short term, profits may be extremely volatile and subject to a number of accounting decisions, especially with respect to costs, that bear little relation to long-term performance. They are also sensitive to cross-country differences in accounting methods, making comparability that much more difficult. These vulnerabilities are particularly true in the initial stages of transition, which are characterized by dramatic changes in accounting systems and practices, imperfect disclosure systems, and short reporting histories.

But there is a more important reason why we take special interest in revenue performance: because of its relation to entrepreneurial success, we find the revenue performance of privatized firms to best reflect the advantages of private ownership. If the cost side of the profit equation seems the bread and butter of most managers, it is because costs relations tend to be known to them (or other company insiders) with a high degree of certainty and because cost-cutting measures are often a matter of relatively standard procedures. Revenues are not only less subject to manipulation and more transparent to an outside observer, but also more future-oriented and unpredictable on the basis of past history. ${ }^{17}$ To capture new sources of revenues or to regain the disappearing ones is a matter of entrepreneurial, risk-taking activity even in mature economies. As The Financial Times put it, "costs are essentially static, since they encapsulate the past history of the company. Revenues are dynamic, reflecting the ebb and flow of economic activity, customer preference and pricing signals." 18

${ }^{17}$ We analyze differences in the way state and privatized firms approach uncertainty and risks inherent in restructuring of their activities in a forthcoming paper.

18 "It's the revenues, stupid," The Financial Times, Dec. 27, 1996. The focus on revenues could distort our performance comparisons if the superior revenue performance of privatized firms could be attributed to mergers or acquisitions. There is, however, no evidence of any mergers or acquisitions in our sample. We examined the annual revenue changes of all privatized firms in the sample, and for all those that increased their revenues by over $25 \%$ within a single year, we evaluated the employment changes. The highest annual employment increase among those firms was about $18 \%$, and it was a small firm that increased its employment from 176 to 209 employees -- hardly a merger-generated growth. The next highest annual employment increases among the same group of firms were $14.5 \%$ and $2.5 \%$, respectively, indicating no major mergers or acquisitions in our sample. Another distortion could have been introduced if state firms were more likely than privatized companies to split or otherwise contribute a part of their assets to other entities. On this question we have 
These characteristics of costs and revenues are particularly true in the environment of transition, where the gross cost inefficiencies of the past are easily identifiable, as are, most often, their most obvious remedies. On the other hand, skills required to restructure most companies -when their old markets have collapsed, imports have introduced overnight competition from the most advanced world producers, and buyers have become more careful and demanding -- are not that different from those needed to start a new business; within some additional constraints (such as the existing labor force or the already available machinery), the post-communist firms must reinvent their products and find markets in which they can be sold

direct evidence and it excludes such possibility: 20 privatized firms and only 11 state firms contributed some portion of their assets to other entities, and the effects of these contributions on employment and revenue measures used in our equations were approximately similar for state and privatized firms. 
The evaluation of revenue performance of state and privatized firms alike must recognize the significant downward pressure that the early stages of transition put on revenues and employment. First, the very size of these firms was often not dictated by economic calculation; ${ }^{19}$ second, the loss of some markets (such as COMECON) and/or the marketization of the remaining activities forced most of them to discontinue slow-selling products, spin off less productive assets, shed inefficient operations, and cut employment. ${ }^{20}$ This restructuring is common to state and privatized firms, and we view the resulting drop in revenues and employment as a necessary consequence of past distortions: we refer to it as the transition or marketization effect that all firms must cope with.

It is against this common effect that we evaluate the performance of privatized firms. We assume that the difference between the state and privatized firms -- which we label the privatization effect -- reflects the success (or failure) of privatized enterprises in dampening the transition effect and accelerating the expected conversion to a "normal" market economy. The privatization effect -- across all types of owners of privatized firms as well as for particular types of owners (foreign or domestic, individual or institutional, insider or outsider) -- is the focus of this paper.

Although we emphasize the revenue performance most, we also contrast other performance indicators of privatized and state firms, beginning with their employment behavior. Differential abilities of privatized and state firms to generate revenue growth have potentially significant impact on their ability to sustain or generate employment. This impact is of particular interest to policymakers in the transition economies, where labor layoffs are among the most feared aftermaths of -- and the most socially and politically threatening deterrents to -- large-scale privatization. We augment the analysis of revenue and employment changes with an evaluation of

\footnotetext{
${ }^{19}$ Enterprises in Eastern Europe tend, on average, to be larger than those in comparable developed market economies; see Kornai (1992).

${ }^{20}$ Balcerowicz, Gray and Hashi (1997) document the staggering decline of output and employment in the initial stages of transition.
} 
revenue per employee performance, which proxies for labor productivity effect. Finally, we discuss the cost effects of privatization, with labor and material costs per unit of revenues as the measure of performance.

\section{Performance evaluation}

For each of the four performance measures -- revenues, employment, revenue per employee and costs per unit of revenues -- we use rates of growth to compare the performance of privatized and state firms. To smooth out the year-to-year variations of these rates, we annualize growth over the entire period of interest. ${ }^{21}$ For privatized firms, the growth rate is annualized between the year of a firm's privatization and 1993 (the final sample year), ${ }^{22}$ so that it reflects the post-privatization performance. Since the year of privatization varies among privatized firms, the rate annualizes performance of different "vintages" of privatized firms over different time horizons. To assure comparability with performance of state firms, we annualize the performance of the latter over all possible time periods (1990-93, 1991-93, and 1992-93). ${ }^{23}$

The comparisons are based on a multivariate analysis which evaluates the performance of privatized firms through an additive performance contrast to state firms. The analysis proceeds in two stages. We begin with estimating the general effect of privatization, i.e., the average performance contrast across all categories of private owners and all countries. ${ }^{24}$ Here, we relate growth of a firm's performance, $A R G P E R F$, to the initial value of its performance, INIPERF, and the its ownership type, $P R V$ (with $P R V=1$ if the firm is privatized and 0 otherwise):

${ }^{21}$ That is, if $P E R F_{t}$ denotes the value of a firm's performance measure in year $t$, the annualized rate of growth of performance, $A R G P E R F$, is an imputed rate which satisfies $P E R F_{T} / P E R F_{t}=(1+A R G P E R F)^{(T-t)}$ over the appropriate time interval $(T-t), T>t$.

22 By the "year of privatization" we mean the year in which the new owners assumed a de facto control of a firm, rather then the year in which the firm's shares were officially distributed. [The survey question pertaining to the date of privatization asked the CEO of a privatized firm to provide the date when "(a) the voting power of private parties in the company rose above the percentage formally sufficient to block major decisions, or $(b)$ if a significant portion of the company shares was privatized through vouchers, when new owners became active in company affairs (even if before their shares were distributed). "] The difference is of importance in the Czech Republic, where new owners could assume control in 1992 (when the auctions in the first wave of privatization were undertaken) even though the shares were distributed later.

23 Ideally, the performance of each "vintage" of privatized firms ought to be compared with the performance of state firms annualized over the matching period. However, our data set is not large enough to allow separate comparisons for each vintage of privatized firms. The smallest "vintage," that of 1990, consists of 15 firms only; even the 1992 vintage, with 58 firms, becomes quite small when divided between three countries, various ownership categories, etc. This forces us to group all vintages of privatized firms together. As a result, firms within the single "privatized firms" category have their postprivatization performance evaluated over different periods of time: those privatized in 1990 between 1990 and 1993; those privatized in 1991 between 1991 and 1993, and those privatized in 1992 between 1992 and 1993. This raises the question of the period over which the performance of state firms should be evaluated so as to "match" the evaluation of privatized firms. Clearly, no such matching is possible within any single period of time. Instead, we estimate the post-privatization performance of privatized firms against the performance of state firms evaluated, alternatively, between 1990-93, 1991-93, 1992-93. These estimations produced three sets of estimates, depending upon which of these three periods was used to evaluate the performance of state firms. In virtually all cases, our results are invariant with respect to the time period used: the estimates retain their signs and significance across all three sets.

${ }^{24}$ Complete definitions of all dependent and explanatory variables are provided in Appendix A. 


$$
A R G P E R F=a+a_{0} I N I P E R F+\beta P R V+e
$$

where $\beta$ measures the incremental performance effect specific to privatized firms. The use of additive effect for privatized firms allows us to separate the transition and privatization effects. ${ }^{25}$ We interpret $?=\beta P R V+e_{2}$ as the the (average) privatization effect specific to private ownership. The remaining part of equation (1), $t=a+a_{0} I N I P E R F+e_{1}$ can then be interpreted as the performance element common to all firms, i.e., the transition effect. In equation (1), this effect consists of two components: the mean effect $a$ and the initial position effect $a_{0} I N I P E R F$. (Note that for revenue and employment regressions, the initial performance gauges the initial size of the firm.)

Since equation (1) evaluates only the post-privatization performance of privatized firms, any contrasts with state firms could potentially reflect (i) a selection bias in the form of a choice (deliberate or otherwise) of better firms for privatization and/or (ii) a moral hazard effect in the form of a deliberate decision by insiders to bring down the pre-privatization performance of a state firm to enhance the likelihood of acquiring it. To ensure that neither of these biases drives our results, we compare the pre- and post-privatization performance of the same set of state and privatized firms, including and excluding firms which ended up in the hands of insiders. We also subject equation (1) to a number of tests to assure that the privatization effect does not proxy for other factors. These factors -- country and industrial sector in which a firm operates, time of privatization, etc. -- are typically defined as 0-1 dummy variables, and injected into equation (1) as additive and/or interactive terms. Where these factors are significant, we modify the estimates of the transition and privatization effects accordingly

The privatization effect in equation (1) is the average effect across all owners of privatized firms. It may, of course, vary with a particular type of ownership; indeed, it need not be positive for all types of owners, and there is a considerable discussion concerning the effectiveness of different private owners in the transition environment. In the second part of the analysis, we replace the privatization variable $P R V$ in equation (1) with the dummy variable $O W N R_{i}$, which identifies the largest owner of a privatized firm. ${ }^{26}$ This allows for evaluation of privatization effects for different types of owners -- the ownership effects, so to say. Since there are pronounced differences in the preponderance of different types of private owners across the three countries, we also augment the equation with country variables ( $H U=1$ for Hungary and 0 otherwise, $P L=1$ for Poland and 0 otherwise). These changes yield equation (2) below:

${ }^{25}$ The choice of state firms to provide a norm (or benchmark) against which privatized firms are evaluated is not arbitrary. While the performance of state firms falls within a relatively narrow range, the performance of privatized firms shows too much variability to serve as a clear performance standard. Indeed, the gamut of firm-level actions it emancipates is one of the most striking (and telling) aspects of privatization, which deserves a separate treatment. We discuss this issue in a forthcoming paper.

${ }^{26}$ As explained earlier, firms in our sample have very concentrated ownership. Accordingly, we identify a firm's ownership type with its largest owner. With few exceptions (to be noted in the text), we found the identity of other owners to be generally insignificant. 


$$
\text { ARGPERF }=a+a_{0} I N I P E R F+S_{i} \beta_{i} O W N R_{i}+?_{1} H U+?_{2} P L+e
$$

With $\beta_{i}$ measuring the incremental performance effect specific to a privatized firm with a particular type of largest shareholder, ? ${ }_{i}=S_{i} \beta_{i} O W N R_{i}+e_{2}$ is the privatization effect for the $i$-th type of owner. The remainder of equation (2), $t_{C}=a+a_{0} I N P E R F+?_{1} H U+?_{2} P L+e_{1}$ represents the transition effect, which now includes country effects, $?_{1} H U$ or $?_{2} P L$, in addition to the mean and initial position effects.

All equations in this paper are estimated by ordinary least squares (OLS) with the White heteroscedasticity consistent estimator (1980) estimating the asymptotic covariance matrix. All regressions were run using LIMDEP 6.0 econometric software .

\section{TRANSITION, PRIVATIZATION AND PERFORMANCE}

We begin by evaluating the average effect of privatization in the early stages of transition. Bivariate summary measures of revenue and employment performance of state and privatized firms, shown in Figure 1 below, provide the background. (New private firms are included for comparative purposes.) Over $80 \%$ of state and over $56 \%$ of privatized firms lost revenues in each year between 1990 and 1993, with most of them losing over 30\% of their sales between 1990 and 1991 alone. The labor market story is even starker, with nearly all state and a majority of privatized firms losing employment over the entire sample period. It is a telling indication of the magnitude of the transition effect that even the few state firms with growing revenues had to decrease employment during the first four years of the transition to reduce the endemic overmanning of the old socialist enterprises. 


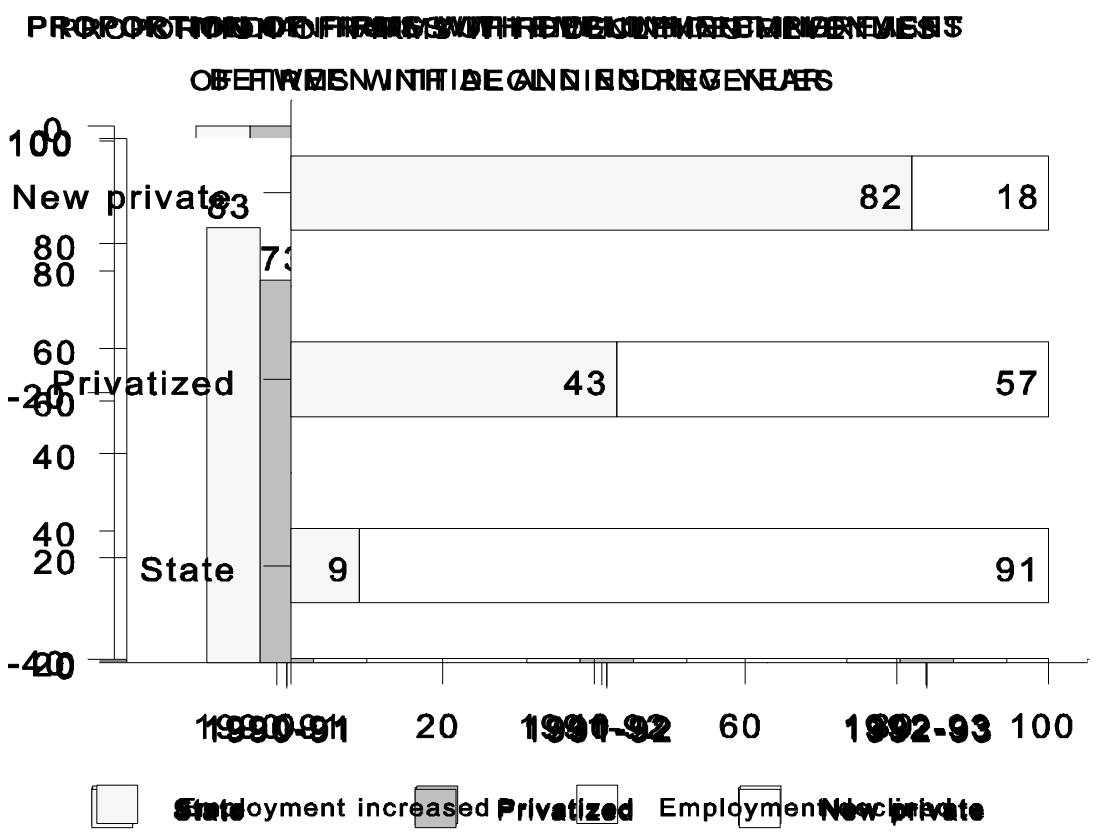

But if Figure 1 shows the strength of the transition effect, it also offers a glimpse into the power of the privatization effect. The percentage of privatized firms losing revenues in each of the sample years is considerably lower than the percentage of state firms; among revenue-losers, privatized firms tend to arrest the decline markedly faster than state firms; and nearly half of privatized firms managed to create new employment over the entire period. ${ }^{27}$

Indeed, when the transition and privatization effects are isolated, the performance impact of privatization is quite dramatic. The table below shows the transition and privatization effects estimated from the revenue, employment, revenue per employee, and cost per unit of revenue versions of equation (1). ${ }^{28}$

TABLE 1 TRANSITION AND PRIVATIZATION EFFECTS

${ }^{27}$ It might be objected that our results are skewed by a possible survival (exit) bias, since there may be more liquidations among privatized firms. There is no evidence, however, that this is the case; there have been many closures of state firms under state enterprise laws (particularly in Poland) and relatively few closures (as opposed to reorganizations) of mid-sized and large state or privatized firms under bankruptcy laws in the three countries (Balcerowicz, Gray and Hashi, 1997). It is also worth noting that had such a bias toward the exit of non-viable private firms existed, it would have provided a strong, independent argument in favor of privatization as an efficient resource reallocation mechanism - even while biasing our results.

28 These estimates result when performance of state firms is evaluated over the entire sample period, 1990-93. Evaluating this performance over the remaining two periods (1991-93 and 1992-93) affects neither the significance nor the order of magnitude of the estimates. We therefore use the first set of estimates throughout the paper; full regression statistics for the remaining two sets are reported in Table A.2, Appendix A. 


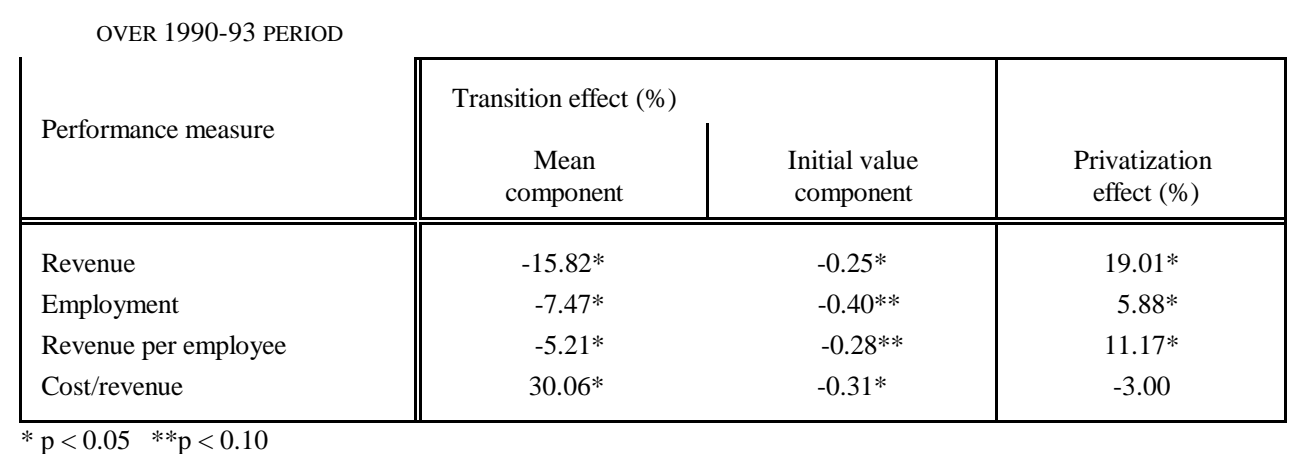

Note first the enormous downward pressure exerted by the transition: the mean component of the transition effect depresses (annual) revenue growth by almost $16 \%$ and employment growth by over 7\% . Larger firms are hit harder: the initial value component indicates that revenue and employment losses increase with the firm's size ${ }^{29}$. Not surprisingly, the pressure extends to the excess of revenues over costs: the mean component of transition effect increases the costs' share of revenues at the annualized rate of $30 \%$. (Here, the initial value component works in the opposite direction, as gross inefficiencies tend to be easier to remove.)

The transition effect should, of course, be understood as a temporary phenomenon: the failure to generate revenue growth or sustain employment cannot be forever attributable to the change of economic regime. Moreover, the (mean component of the) transition effect represents our interpretation of the average performance of state firms, and no firm can survive revenue declines of double-digit magnitude over long periods of time. ${ }^{30}$ Thus, the privatization effects in Table 2 suggest that privatization may the most efficient antidote to the shock of transition: privatized firms outperform state firms on all performance measures, and on all except costs per dollar of revenue the margins are very large and highly significant.

This is particularly true of revenue growth, where the estimated privatization effect $(+19.01)$ is at least as strong as the mean component of the transition effect (-15.82). Not only does the restructuring undertaken by privatized firms allow them to moderate significantly their revenue losses vis-a-vis their state counterparts, but it actually allows about half of them to generate revenue gains: estimates of equation (1) imply that a privatized firm with initial revenues of about US\$ 6 million (approximately the median initial revenue of state and privatized firms in the sample) would overcome the transition effect, experiencing a modest $1.5 \%$ annualized growth

${ }^{29}$ It is noteworthy in this connection that the initial revenue of a firm is a very powerful determinant of its later revenue growth, with larger firms suffering sharper revenue declines. The reasons for this are not apparent from our survey, but are not hard to conjecture. The larger the firm, the more political clout it used to have, and the less business justification was needed for its operations, under the old regime. It was also more likely to have been in a quasi-monopolistic position and to have produced goods for export to the COMECON countries, and less likely to be able to respond to a fast-changing environment.

30 If some state firms survive nevertheless while continuing to show inferior performance, their inferiority will have to be ascribed to some sort of "state-ownership effect," rather than blamed on the difficulties of transition. 
between 1990 and $1993 .{ }^{31}$ In marked contrast, throughout the same period state firms would be losing revenues regardless of their size, with the median-sized firm suffering an annualized decline of $17.5 \%$ per year. ${ }^{32}$

Differences of this magnitude testify to the strength of the privatization effect, as well as to the odds that older firms must overcome during the early years of the transition. Our estimates belie the existence of any tangible "privatization shock" which afflicts the behavior of the firms that undergo swift ownership changes. On the contrary, what we observe is a very severe shock of marketization, which affects the performance of both types of firms, and to which privatization provides a powerful remedy

${ }^{31}$ The expected value of the transition effect - the sum of the mean and initial revenue components - for firms with initial revenues of $\$ 6 \mathrm{mln}$ is $-17.5 \%$, while the expected value of the privatization effect is $19 \%$.

${ }^{32}$ As startling as these estimates may appear, they reflect bona fide differences in the ways state and privatized firms restructure their activities: only 6 of the 89 state firms in the sample managed to increase their revenues over the entire 1990-93 period, while 33 of the 81 privatized firms did so in the wake of their privatization. This inferior performance of state firms holds regardless of the time period: between 1991 and 1993 only 11 state firms increased their revenues, and only 12 did so between 1992 and 1993 (See Figure 1 above). 
It would be quite surprising if the superior ability of privatized firms to generate revenue growth (or moderate revenue declines) did not affect their employment behavior -- and indeed it does. The average employment effect of privatization is nearly $6 \%$, significantly above zero. ${ }^{33}$ As we shall see shortly, this effect is somewhat affected by the behavior of insider-dominated firms; however, with the exception of worker-owned firms, it does not come at the expense of labor productivity. This suggests that the increased revenues of privatized firms make up for what would otherwise have to be greater employment reductions (as compared with state firms)

Our data indicate quite clearly that privatization arrests employment decline and often creates new employment. Privatization is not a matter of trading off long-term employment benefits for short-term costs - the positive employment impact of privatization is practically immediate, showing that privatization is an antidote to the deadly cycle of revenue falls, followed by layoffs, followed by further revenue falls, etc. ${ }^{34}$. So far as we can see, there are simply no costs

33 It must be remembered that this effect compares the employment of privatized firms with their state counterparts, and does not gauge absolute changes. These, on average, were negative even among privatized firms, a robust indication of the extent of overmanning of their communist predecessors. With the mean component of the transition effect at $-7.47 \%$, and the size component lowering it by $.4 \%$ for each additional 100 workers, the transition constitutes a drag that is very difficult to overcome. Our estimate of the transition effect is quite consistent with the results of Pinto and van Wijnbergen (1996), who report a 27\% drop in employment among large (average 1992 employment of about 3,000 employees) Polish state enterprises, and Balcerowicz, Gray and Hashi (1997), who report 32, 47 and 33\% decline in employment of the largest 200 firms in the Czech Republic, Hungary, and Poland, respectively, between 1989 and 1993.

34 It would be of considerable interest to estimate the employment impact of revenue changes. However, including revenue changes in the employment version of equation (1) would expose the estimates to a simultaneous equation bias, and our data set did not include enough instruments to allow simultaneous estimation. We have therefore opted for another way of gauging the relation between employment and revenues of the firms in our sample, namely estimating the ratio of the latter to the former. The results, presented below, confirm that firms suffering revenue declines lower employment while firms 
to privatization in this respect: once the macroeconomic reforms are in place and the system of pervasive subsidization is stopped or significantly reduced, privatization is the dominant employment strategy in transition. ${ }^{35}$

Revenue per employee results are, of course, a firm-level version of the story foretold by the average revenue and employment effects. But the measure also proxies for the labor productivity, and therefore provides an independent estimate of efficiency of state and privatized firms. The negative mean component of the productivity effect indicates that heavy employment layoffs among state firms fail to arrest the decline in labor productivity; privatized firms, on the other hand, tend to reverse the slide despite relatively smaller labor reductions. Thus, while state firms seem to deal with the shock of transition primarily by downsizing, privatized firms are more successful at regaining their markets and laying foundations for future growth.

increasing employment tend to enjoy revenue growth.

35 This suggests that if employment subsidies are deemed desirable, they would be more effective if directed to private (including privatized) rather than state firms. 
The cost side of operations -- as measured by the decline of costs' share of revenues -shows the least contrast between state and privatized firms. Although the privatization effect is negative (at -3.00), suggesting that privatized firms are gaining on state firms in terms of cost efficiency, the average effect across all privatized firms is not consistent enough to be significant. This confirms our prior expectations of cost cutting in transition environment. Most communist enterprises had worked under a "cost plus" system, in which prices of their products had been determined by their production costs, however irrational and uneconomic these may have been. ${ }^{36}$ As a result, most enterprises had bloated expenditures and failed to follow even elementary costsaving production procedures. Given these obvious inefficiencies, their removal after the switch to a market regime tends to be a rather straightforward, more a matter of political will than entrepreneurial skill. ${ }^{37}$

Before turning to the evaluation of performance differences among different types of private owners, we would like to reiterate the average impact of privatization across all owners by illustrating the costs of delayed privatization. Figure 2 below illustrates the strength of revenue, employment and labor productivity privatization effects estimated from equation (1). The graphs

${ }^{36}$ Hungary had in theory abandoned the "cost plus" system of pricing during the period of its economic reform in the 1980's. In fact, however, most prices were controlled, and enterprises were able to bargain to make sure that they could cover their costs. Kornai (1990).

${ }^{37}$ Cost are, to be sure, related to revenues. When the latter fall precipitously, it may be very difficult to lower the former quickly enough to make up for lost sales, given that a significant portion of the costs is fixed. But we do not have in our data sufficient information concerning fixed costs to be able to measure any lag in cost adjustment this may entail. In fact, in our discussion of costs, we are always referring to labor and material costs, exclusive of the cost of capital, depreciation, etc. Still, we do observe the persistence of the transition effect in the costs-per-unit-of-revenues over the first few years of the transition, which means that firms do not make immediate cost adjustments to their falling revenues. This may be due to two factors: (1) the reduction in most firm's employment figures lags somewhat behind revenue losses, especially at the beginning of the transition, when the firms have not yet learned that they cannot expect their losses to be temporary or to be made up by government assistance; (2) at the beginning of the transition, the prices of most material inputs are severely distorted and they are adjusted only over time. This means that the rising costs of a firms' inputs percolate over time in a way that, except when substitution of imports in an option, is next to impossible for the firm to anticipate. 
show the relative performance of privatized and state firms with identical initial values of each performance measure. In each case, the vertical axis measures the ratio of the performance measure of a privatized firm to that of a state firm. The horizontal axis is set where the ratio equals 1, i.e., at the point where the privatization effect is 0 . (Shaded areas mark the confidence intervals around the mean values.)

In Section 5, we test these results for the presence of any such bias or moral hazard effects which could handicap state firms -- and find none. We also verified that the privatization effect is not limited to a particular country, industrial sector or a particular vintage of privatized firm. ${ }^{38}$ It is interesting to note that inclusion of country effects has no significant effect on either the sign or the magnitude of the privatization effect. The superior performance of privatized firms reflects the strength of the privatization effect alone: it is common to all three countries (despite some pronounced differences in their privatization programs) and it does not significantly depend on sectoral or temporal differences. It does, however, vary between various types of private owners; we turn now to this dependence.

REVENUEFANCE
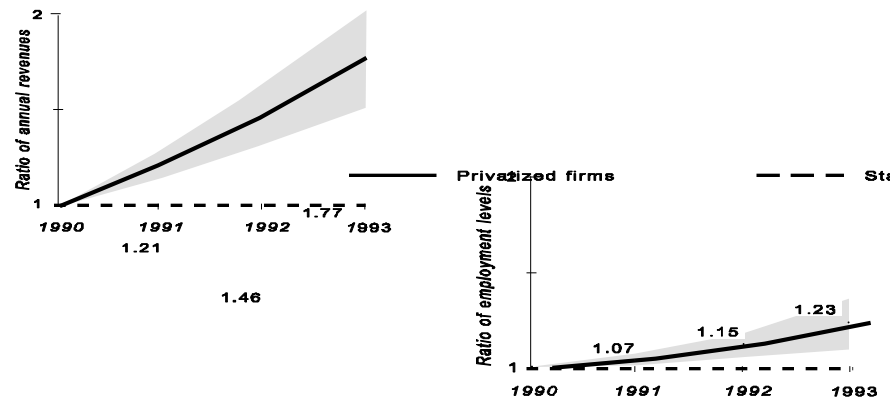

REVENUE PER EMPLOYEE

\section{OWNERSHIP EFFECTS}

The privatization effect estimated from equation (1) is the average effects across all owners of privatized firms. Equation (2) allows its estimation for particular categories of private

${ }^{38}$ To avoid presenting an overwhelmingly large number of regression results, we do not report the results of these tests here. They are available from the authors upon request. 
owners. ${ }^{39}$ However, because of a relatively small number of observations within some categories (see Table B.2, Appendix B), the estimates of some ownership effects -- even though of considerable magnitude -- are not precise enough to allow statistically defensible inferences. We therefore augment these results by estimating the ownership effects for all outsider-owned firms and all insider-owned firms taken together. Full regression statistics for all estimates are given in Tables A.1 and A.2, Appendix A. Table 2 below provides the estimated privatization effects and indicates their significance levels.

TABLE 2 OWNERSHIP EFFECTS

\begin{tabular}{|c|c|c|c|c|c|c|c|c|c|}
\hline & \multirow{2}{*}{\multicolumn{6}{|c|}{$\begin{array}{l}\text { Privatization effect when the largest shareholder is } \\
\text { Outsider }\end{array}$}} & \multirow[b]{3}{*}{$\begin{array}{c}\text { All insider } \\
\text { owners }\end{array}$} & \multirow{2}{*}{\multicolumn{2}{|c|}{ Insider }} \\
\hline & & & & & & & & & \\
\hline & $\begin{array}{l}\text { All outsider } \\
\text { owners }\end{array}$ & $\begin{array}{l}\text { Foreign } \\
\text { company }\end{array}$ & $\begin{array}{l}\text { Privatiza- } \\
\text { tion fund }\end{array}$ & $\begin{array}{l}\text { Domestic } \\
\text { nonfinan. } \\
\text { company }\end{array}$ & $\begin{array}{c}\text { Individual } \\
\text { owner }\end{array}$ & State & & Managers & Workers \\
\hline Revenue & $18.30^{*}$ & $18.84 *$ & $27.09^{*}$ & $8.54 * *$ & $16.61 *$ & $15.88^{*}$ & $14.51^{* *}$ & $25.14 *$ & 4.65 \\
\hline Employment & $4.01 *$ & $7.26^{*}$ & 0.96 & 3.99 & 3.10 & 1.42 & $10.59^{*}$ & $6.86^{*}$ & $13.76^{*}$ \\
\hline Revenue/employee & $10.37 *$ & $8.29 * *$ & $16.25^{*}$ & $11.20^{*}$ & 19.32 & $17.61 *$ & -0.59 & 11.39 & -7.76 \\
\hline Cost/revenue & $-5.37 *$ & -3.16 & -5.23 & 2.86 & $-18.07 *$ & $-5.70^{* *}$ & $2.17^{*}$ & 4.98 & 0.18 \\
\hline
\end{tabular}

$* \mathrm{p}<0.05 ; * * \mathrm{p}<0.10$

\section{A. OUTSIDER OWNERS}

While privatization provides substantial leverage against the downward pressure of transition, its impact does vary with the identity of the largest owner. Firms owned by outsiders. tend to enjoy a double-digit rate of revenue growth advantage over state firms: for all outside owners combined, the revenue effect is highly significant, as is the positive employment effect. And even though they cut their employment at slower rates, outsider-owned firms nevertheless enjoy significant productivity increases relative to state firms.

${ }^{39}$ Recall that in the context used here, "owner" means the largest shareholder, the equivalency made possible by the high concentration of holdings in the sample. 
The fact that state firms reduce their employment levels faster than outsider-owned firms - which, according to all evidence, are the most aggressive agents of restructuring in the transition economies -- is in itself significant. Although some employment reductions may be forced on state firms by their falling revenues and increasingly hard budget constrains, many observes initially expected the nomenklatura managers in control of state firms to avoid large layoffs, at least temporarily, through decapitalization, borrowing, and other practices. ${ }^{40}$ The fact that employment declines of state firms are very deep shows, as others have also observed, that these firms do undertake restructuring. ${ }^{41}$ Where this restructuring seems to be falling short, though, is in its ability to rejuvenate revenue growth, and it is here that outsider ownership makes the most rapid and pronounced difference.

40 As we have already noted, managerial turnover in Central Europe has been enormous, so that it may not be justified to identify the managers in charge of most state companies with the old nomenklatura.

41 Pinto, Belka, and Krajewski (1993) and Pinto and van Wijnbergen (1994) attribute such restructuring to the imminent (at least in the eyes of managers) privatization of these firms. We believe it is primarily the marketization of economic activity that forces these firms to restructure. Most importantly relative to earlier studies, our data indicate that the restructuring lacks effectiveness vis a vis that of privatized firms. 
As expected, the behavior on the cost side provides the least pronounced contrasts. ${ }^{42}$ For all outsider-owned firms combined, the cost impact of privatization is significant: they tend to reduce labor and material cost as a share of their revenues at a significantly faster pace than state firms (despite the fact that they shed employment at a significantly lower rate.) To the extent to which the costs' share of revenue approximates profit performance, outsider-owned firms appear to significantly improve their profitability vis-a-vis their state counterparts. However, the cost/revenue effect of privatization appears much smaller than either the revenue or revenue per employee effect; in fact, although the cost effect is negative for firms owned by all outsiders except nonfinancial firms -- in addition to a relatively small number of firms in individual ownership categories -- keeps it within the limits of chance variation.

\section{Privatization funds and domestic nonfinancial companies}

The very different revenue performance of privatization funds and domestic nonfinancial companies deserves note, especially in light of the oft-expressed claims that financial investors are generally less active than "strategic" investors. ${ }^{43}$ Financial institutions created in connection with

${ }^{42}$ Cost cutting, we have already argued, is very different from revenue generation. Moreover, although costs are relatively transparent on the level of an individual enterprise, they are also notoriously difficult to compare across countries or industries, especially in the environment of transition. Alterations of product offerings, restructuring of production processes, large variations of revenues and employment, annual changes in price indexes (for inputs as well as outputs), and major revisions of accounting systems all make the identification of systematic differences between privatized and state firms even more difficult.

43 The latter were in fact given preferential treatment among foreign investors by the privatization authorities in 
the mass voucher privatization programs have often been thought as "mutant" owners, inherently passive and largely ineffective. The strong performance of the firms in which privatization funds are the largest owners tends to make such fears look unfounded. ${ }^{44}$ This performance goes beyond revenue generation: firms owned by privatization funds also maintain very tight employment discipline (no other outsider owner has a lower rate of employment growth), allowing them the fastest increases in labor productivity. Indeed, our results seem to indicate that privatization funds, perhaps because they are new institutions, are less likely to be burdened with the old

certain countries, including Hungary and Poland.

${ }^{44}$ The Czech privatization funds have been the subject of much criticism. Their performance has been blamed by some for the slowing down of the Czech growth rate, and allegations of fraudulent asset diversions have been viewed as undermining investor confidence in the Czech economy. We take no stand with respect to these allegations, most of which are addressed to the behavior of the Czech funds in the period after our study. Whatever the merit of these (perhaps somewhat too hasty) criticisms, our data show clearly that the firms owned by these funds restructure at least as effectively as those owned by any other type of owner. 
inefficient routines of other institutional actors (such as domestic production companies or old banks) and are in fact much better at revitalizing the privatized companies than these other owners. $^{45}$

The relatively weak revenue performance of domestic nonfinancial companies as owners of privatized firms -- the difference between firms owned by these owners and state enterprises is only borderline significant -- is also interesting. If these firms generate significant gains in labor productivity, the gains seem to result primarily from employment reductions, at least as compared to other outside owners. Their cost behavior is not significantly different from state firms; if anything, the cost effect of privatization carries a positive sign (the only such case among outsider owners) characteristic of insider-owned firms. "Domestic non-financial companies" may be a label, we suspect, that hides more complex insider holdings. Performance of firms owned by these companies provides some support for the belief that this type of ownership arrangement is often a "defense tactic" used by the insiders in control of postcommunist enterprises to insulate themselves from outside monitoring and the threat of more radical restructuring that other forms of privatization may bring.

\section{Foreign owners}

45 It should be noted, however, that despite the inclusion of country dummies in equation (2), the strong performance of privatization funds cannot be fully separated from their Czech environment, since no contrast with financial institutions in Hungary and Poland is possible in our sample. Although it is thus possible that the strong performance of these institutions "soaks up" some other aspects of superior performance of Czech privatized firms, such factors cannot explain all of the privatization funds' superior performance. For a discussion of the structure and performance of the Czech privatization funds as well as potential problems facing them, see Claessens, Djankov and Pohl (1997b) and Coffee (1996). 
Foreign investors provide less of an edge than might have been expected. Although foreign ownership brings a significant improvement of revenue performance, its impact is no stronger than that of domestic outsiders. ${ }^{46}$ This result is somewhat unanticipated, as financial resources, managerial know-how, and corporate governance expertise of foreign strategic investors ${ }^{47}$ are often seen as giving an instant advantage to firms in which they invest. Our data do not allow us to ascertain why this advantage does not materialize. It may be that foreign owners are initially ill at ease in an environment that is relatively alien to them; it may be that the transfer of technological and managerial know-how requires more time than our sample period allows; it is also possible that domestic owners (at least those who act as real agents of change) may have less restricted access to both external financing and know-how than is often believed.

46 The difference between the privatization effect for foreign-owned firms (19.06 when performance of state firms is evaluated over 1990-93 period, with a standard error of 5.04) and firms owned by other outsiders (17.64 with a standard error of 4.35) is insignificant regardless of the time period over which the performance of state firms is evaluated: the $\mathrm{F}$ statistics for the test of equality of the privatization effects are $F_{1,171}=0.062(p=0.81), F_{1,171}=0.03(p=0.85)$, and $F_{1,171}=$ $0.04(\mathrm{p}=0.84)$ for each of the three periods, respectively.

${ }^{47}$ In practically all cases in our sample foreign companies that hold the largest stake in a firm are themselves in the same or similar line of business. 
Note also that foreign-owned firms, alone among outsider owners, have a significant employment effect of privatization. Indeed, the pace at which foreign-owned firms reduce employment is significantly slower than that of other outsider-owned firms ${ }^{48}$ and not significantly faster than that of employee-owned firms. ${ }^{49}$ These results are interesting, particularly because they do not seem to derive from superior revenue performance alone. Not only is the revenue effect of foreign-owned firms not significantly stronger than that of other outsider owners, but the improvement in their labor productivity is questionable: the labor productivity effect for foreignowned firms exceeds that of state firms by a margin that is barely significant, and only when put against the performance of state firms over the 1990-93 period. When performance of state firms is evaluated over 1991-93 or 1992-93 period, the performance of foreign firms is not statistically distinguishable from that of state firms. Again, our data allows only speculative interpretations of this performance. ${ }^{50}$

48 The difference between the average privatization effect for foreign-owned firms ( 7.27 when performance of state firms is evaluated over 1990-93 period, with a standard error of 2.13) and other outsider-owned firms (2.17) is significant regardless of the time period over which the performance of state firms is evaluated: the F-statistics for the test of equality of the privatization effects are $\mathrm{F}_{1,161}=4.16(\mathrm{p}=0.04), \mathrm{F}_{1,161}=3.91(\mathrm{p}=0.05)$, and $\mathrm{F}_{1,161}=5.21(\mathrm{p}=0.02)$ for the 1990-93, 1991-93 and 1992-93 periods, respectively.

49 The difference between the average privatization effect for foreign-owned firms and employee-owned firms is insignificant regardless of the time periods over which the performance of state firms is evaluated: the F-statistics for the test of equality of the privatization effects are $\mathrm{F}_{1,156}=1.46(\mathrm{p}=0.23), \mathrm{F}_{1,156}=1.35(\mathrm{p}=0.25)$, and $\mathrm{F}_{1,156}=1.75$ ( $\left.\mathrm{p}=0.19\right)$ for the 1990-93, 1991-93 and 1992-93 periods, respectively.

${ }^{50}$ It may be that foreign owners are reluctant to fire workers in an environment in which mistrust of foreign investors is common and they need to build local good will. It may also be that foreign owners are prevented from laying off workers by explicit or implicit agreements in their purchase contracts. Possibly, foreign owners are expanding their productive capacities but this does not yet show in their revenue figures. Or perhaps they can afford a longer-term perspective and are simply not as aggressive in cost cutting as the more "hungry" domestic outsider owners. 
The state as the largest shareholder

The success of partially privatized firms in which the state remains the largest owner offers perhaps the biggest surprise of all -- and a paradox of sorts, given the poor performance of firms wholly owned by the state. This superior performance also goes against the results of prior research from other countries which suggested that partial privatization fails to produce any improvements in performance and that mixed state-private firms often do worse than fully stateowned companies. ${ }^{51}$ Our results, by contrast, show that the privatization effect for firms in which the state continues to hold the largest stake is significant and large enough not to be statistically distinguishable from the effect of other types of private ownership.

${ }^{51}$ Boardman and Vining (1989). 
The conflict between our results and those of prior research may point to a somewhat special situation of Central Europe. While in some countries partial privatizations may reflect the governments' unwillingness to relinquish control of enterprises they consider of continued political or strategic importance, continued partial state ownership in Central Europe often results from the state's failure to find appropriate new owners or from possession of various partial holdings with respect to which it has no intention of acting as an active owner. Consequently, the state as a partial owner is very often passive and allows the other owners to take control. ${ }^{52}$ Indeed, our data indicate that when the state is the largest shareholder, proxy votes accrue to the second largest owners, but in all other cases they accrue to the largest owner.

If the hypothesis of state passivity is correct, it suggests that the performance of privatized firms in which the state is the largest owner has less to do with the state itself than with its largest private partners. To verify this, we re-estimated equation (2), splitting firms in which the state was the largest owner by the identity of the second largest owner (they were in all cases either privatization funds or domestic nonfinancial companies). ${ }^{53}$ The privatization effects for the split grouping are given in Table 3 below.

TABLE 3 IMPACT OF PRIVATIZATION WHEN STATE REMAINS THE LARGEST OWNER

52 Indeed, even with respect to enterprises in which the state is the sole owner, neglect is often the rule. But whereas the state as a partial owner can free-ride on the efforts of other owners, the firms controlled by state as the sole owner suffer from the absence of monitoring. For the behavior of the state as a partial owner in Central Europe, see Pistor and Turkewitz (1996).

53 The important question here is whether the identity of the owners other than the state determines the performance of a partially privatized firm. Whether it is always the second largest owner -- rather than some further coalition of private owners -- that is decisive for the firm's performance might depend on who the other owners are. 


\begin{tabular}{|c|c|c|}
\hline \multirow{2}{*}{ Private shareholder } & \multicolumn{2}{|c|}{ Privatization effect when the private shareholder is } \\
\hline & the largest owner & the second largest owner (next to the state) \\
\hline Privatization fund & $28.33^{*}$ & $24.92 *$ \\
\hline Domestic nonfinancial firm & $8.88^{* *}$ & 4.10 \\
\hline
\end{tabular}

These results confirm our conjectures. The performance of privatized firms in which the state as the largest owner is accompanied by a particular private party as the next largest owner is statistically indistinguishable from the performance of firms in which the same private party is the largest owner. ${ }^{54}$ When the state is aligned with privatization funds, which are generally strong performers, the revenue performance picks up significantly. But when it is joined by weak performers (private nonfinancial firms), its revenue performance is indistinguishable from that of wholly state-owned firms.

54 The difference between the privatization effect for firms in which state is the largest owner and privatization funds the second largest owner (24.92 when performance of state firms is evaluated over 1990-93 period, with a standard error 9.10 ) and firms in which privatization funds are the largest owner (28.33 with a standard error of 6.32) is insignificant regardless of the time period over which the performance of state firms is evaluated: the F-statistics for the test of equality of the privatization effects are $\mathrm{F}_{1,166}=0.08(\mathrm{p}=0.77), \mathrm{F}_{1,166}=0.09(\mathrm{p}=0.76)$, and $\mathrm{F}_{1,166}=0.09(\mathrm{p}=0.76)$ for each of the three periods, respectively. The same is true for the difference between the privatization effect for firms in which state is the largest owner and private nonfinancial companies the second largest owner (4.09 when performance of state firms is evaluated over 1990-93 period, with a standard error of 11.41 ) and firms in which private nonfinancial companies are the largest owner (8.88 with a standard error of 4.91): the F-statistics for the test of equality of the privatization effects over the three periods are $\mathrm{F}_{1,166}=0.16(\mathrm{p}=0.69), \mathrm{F}_{1,166}=0.18(\mathrm{p}=0.67)$, and $\mathrm{F}_{1,166}=0.19(\mathrm{p}=0.66)$ for each of the three periods, respectively. 


\section{B. INSIDER OWNERS}

As a group, insider-owned firms shed employment at significantly lower rates than either state or other private companies ${ }^{55}$ and their labor productivity effect is significantly below that of outsider-owned firms. ${ }^{56}$ Cost declines among insider-owned firms are significantly smaller than those of state firms: it is solely on the strength of the performance of outsider-owned firms that the cost effect of privatization averaged across all private owners carries a negative sign.

55 The difference between the average privatization effect for insider-owned firms and outsider-owned firms is significant regardless of the time periods over which the performance of state firms is evaluated: the F-statistics for the test of equality of the privatization effects are $\mathrm{F}_{1,162}=3.50(\mathrm{p}=0.06), \mathrm{F}_{1,162}=3.13(\mathrm{p}=0.08)$, and $\mathrm{F}_{1,162}=3.96(\mathrm{p}=0.05)$ for the 1990 93, 1991-93 and 1992-93 periods, respectively.

56 The difference between the average revenue-per-employee effect for insider-owned firms and outsider-owned firms is significant regardless of the time period over which the performance of state firms is evaluated: the F-statistics for the test of equality of the privatization effects are $F_{1,154}=2.72(p=0.10), F_{1,154}=2.72(p=0.10)$, and $F_{1,154}=3.03(p=0.08)$ for the 1990-93, 1991-93 and 1992-93 periods, respectively. 
The contrasts for all insider-owners, however, hide pronounced differences between managerial and employee ownership. ${ }^{57}$ For employee-owned firms, the revenue effect of privatization is both marginal and statistically insignificant: in terms of their revenue performance, these firms are virtually indistinguishable from state firms, and significantly below outsider-owned firms. ${ }^{58}$ Employees in control of a firm also show a significantly lower propensity to trim employment than outsiders, a result which is neither surprising nor indicative of any desirable characteristics of postprivatization behavior. Excessive disposition to protect employment is often perceived as a deficiency of employee ownership, and the confirmation of this behavior is particularly striking in our sample, where the revenue performance of employee-owned firms is not significantly different from that of state firms of comparable size. As a result, the labor

57 We should point out that all employee-owned firms in our sample were operating in Hungary. However, since we were relatively confident that the attributions of ownership of firms leased to employees (excluding ESOPs) were reliable, we re-estimated equation (2) with these firms included as employee-owned. (There were 2 such firms in Hungary and 5 in Poland; the Czech privatization programs gave no special concessions to employees and tended to exclude them from ownership.) The privatization effect actually declined (to 3.75), making these firms even more indistinguishable from state firms.

58 The difference between the privatization effect for employee-owned firms and firms owned by outsiders is significant regardless of the time period over which the performance of state firms is evaluated: the F-statistics for the test of equality of the privatization effects are $\mathrm{F}_{1,171}=6.29(\mathrm{p}=0.01), \mathrm{F}_{1,171}=6.57(\mathrm{p}=0.01)$, and $\mathrm{F}_{1,171}=6.10(\mathrm{p}=0.01)$ for each of the three periods, respectively. 
productivity effect of privatization firms is negative for employee-owned firms, the only case in where the average performance of any kind of privatized company seems to lapse with privatization. 59

That employee-ownership is not effective has been claimed by a number of commentators. ${ }^{60}$ Nevertheless, others have argued that employee ownership is suitable for firms that for political or other reasons cannot be privatized to outsiders, since it is better than continued state ownership. ${ }^{61}$ Our results go against this argument, since they show that employeeowned firms behave like state firms, not only in revenue performance, but also with respect to

59 Admittedly, when the performance of state firms is evaluated over the entire 1990-93 period, the effect is not statistically significant; however, it is significant $(p<0.10)$ when the performance of state firms is evaluated over 1991-93 or 1992-93 periods.

\footnotetext{
${ }^{60}$ Hansmann (1996)

${ }^{61}$ See, for example, Earle and Estrin (1996).
} 
employment and other performance characteristics. ${ }^{62}$ This similarity provides a strong argument against the effectiveness of privatization programs that put employees in control.

62 It is sometimes argued that employee ownership is more likely to occur in weaker firms, which may be sold to workers rather than closed down or in which partial worker ownership may be a quid pro quo for otherwise unavailable wage concessions. Our sample size does not allow us to show conclusively the absence of such a negative selection bias working against employee-owned firms, but we do have some indications that employee-owned firms in our sample were, if anything, better than state firms, at least on average. We discuss this in Section 7 below. 
For managerially-owned firms, the picture is more complicated, and suggests that putting all insiders under a common umbrella is unjustified. ${ }^{63}$ On the one hand, managerial ownership brings a strong and significant improvement in revenue performance vis-a-vis state firms: on the average, manager-owned firms perform like those owned by foreign investors or privatization funds. ${ }^{64}$ On the other hand, their employment behavior is not significantly different from that of employee-owned firms: ${ }^{65}$ they shed employment at a rate significantly slower than state firms and also much slower than outsider-owned firms. Their labor productivity gains are not significantly above those of state firms, ${ }^{66}$ and when the initial costs are controlled for, their cost savings appear to lag those of state firms (although the difference lacks statistical significance.)

A number of commentators have argued that managers under communist system had been selected for their political rather than managerial skills, and that their endemic conflict-of-interest problems make managerial ownership particularly ineffective; indeed, managerial turnover has sometimes been taken as the primary indication of restructuring in the region. As against this, the strong revenue growth of managerially-owned firms is quite striking. One possible explanation suggested by our data is that managerially-owned firms were significantly better than others at the time of privatization: those in our sample had on average an excess of revenues over costs well over 20 percentage points higher than firms controlled by any type of outside owners (or, for that matter, the state). The high excess of revenues over costs may point to having a product less vulnerable to market collapse, ${ }^{67}$ so that the superior revenue performance of managerially-owned firms may be in part a function of antecedent advantages. ${ }^{68}$ If this is the case, the original

${ }^{63}$ Shleifer and Vasiliev (1996) discuss the behavior of manager-owned firms in the early stages of transition in Russia.

${ }^{64}$ The difference between the privatization effect for manager-owned firms is insignificant regardless of the time period over which the performance of state firms is evaluated: the F-statistics for the test of equality of the privatization effects are $\mathrm{F}_{1,171}=0.24(\mathrm{p}=0.62), \mathrm{F}_{1,171}=0.23(\mathrm{p}=0.63)$, and $\mathrm{F}_{1,171}=0.26(\mathrm{p}=0.61)$ for each of the three periods, respectively.

65 The difference between the employment effect of privatization for manager-owned and employee-owned firms is insignificant regardless of the time periods over which the performance of state firms is evaluated: the F-statistics for the test of equality of the privatization effects are $\mathrm{F}_{1,156}=1.42(\mathrm{p}=0.24), \mathrm{F}_{1,156}=1.45(\mathrm{p}=0.23)$, and $\mathrm{F}_{1,156}=1.84(\mathrm{p}=0.18)$ for the 1990-93, 1991-93 and 1992-93 periods, respectively.

66 It should be pointed out, however, that the insignificance of the labor productivity effect of manager-owned firms appears due primarily to the large variability of performance among these firms. Given such variability, the effect is within a chance variation from the average performance of outsider-owned firms: the difference between the labor productivity effect for manager-owned firms and outsider-owned firms lacks significance regardless of the time period over which the performance of state firms is evaluated. The F-statistics for the test of equality of the privatization effects are $\mathrm{F}_{1,153}$ $=0.001(\mathrm{p}=0.97), \mathrm{F}_{1,153}=0.002(\mathrm{p}=0.96)$, and $\mathrm{F}_{1,153}=0.002(\mathrm{p}=0.96)$ for the 1990-93, 1991-93 and 1992-93 periods, respectively.

${ }^{67}$ For example, only $25 \%$ of the managerially-owned firms in our sample faced foreign competition, as opposed to $58 \%$ for all state and privatized firms.

68 This conjecture is further strengthened by the fact that, as we shall see later, the other aspects of manageriallyowned firms' performance do not match their revenue achievements. 
advantages might be frittered away through lax employment policies. Or if managers acquired these firms on preferential terms, as is often the case, perhaps the price of these preferences was a more limited freedom to lower employment.

To summarize, our data indicate that the transfer of ownership rights from the state into private hands is associated with an improvement in revenue performance sufficient for a mediumsized firm to overcome the negative impact of the transition. However, although private ownership gives a powerful boost to performance, a firm's success at overcoming the difficulties of transition is lessened when privatization gives control over the firm to insiders, and employees in particular. This suggests that a choice of privatization techniques does matter, and that in the absence of rapid secondary market corrections (of which there is little evidence to date) some programs are more likely than others to restructure the privatized enterprises. ${ }^{69}$ (The ownership results are summarized in Table 4 below.)

TABLE 4 OWNERSHIP EFFECTS FOR VARIOUS GROUPS OF OWNERS

\begin{tabular}{|c|c|c|c|c|c|c|c|c|c|c|c|c|}
\hline \multirow{3}{*}{$\begin{array}{l}\text { Largest shareholder of } \\
\text { a privatized firm }\end{array}$} & \multicolumn{12}{|c|}{ Growth of performance measure relative to } \\
\hline & \multicolumn{4}{|c|}{ State enterprises } & \multicolumn{4}{|c|}{ Outsider-owned firms } & \multicolumn{4}{|c|}{ Employee-owned firms } \\
\hline & $R E V$ & $E M P L$ & $L B R P R D$ & COST & $R E V$ & $E M P L$ & LBRPRD & COST & $R E V$ & $E M P L$ & LBRPRD & COST \\
\hline Outsiders (all) & + & + & + & + & & & & & & & & \\
\hline Insiders (all) & $\approx$ & + & - & $\approx$ & $\approx$ & + & - & + & & & & \\
\hline Employees & $\approx$ & + & $-1 \approx$ & $\approx$ & - & + & - & $\approx$ & & & & \\
\hline Managers & + & + & $\approx$ & $\approx$ & $\approx$ & $\approx$ & $\approx$ & + & $+*$ & $\approx$ & + & $\approx$ \\
\hline
\end{tabular}

Key: $\quad+$ significantly faster growth; - significantly slower growth; $\approx$ no significant difference; $/$ depending on the period over which the performance of state enterprises is evaluated; $* \mathrm{p} \approx 0.11$

\section{PRE- AND POST-PRIVATIZATION PERFORMANCE; SELECTION BIAS ANALYSIS}

69 A different view, arguing that any form of privatization is likely to bring similarly significant improvements, is presented in Claessens et al.(1997) . 
Eliminating the selection bias hypothesis -- that privatized firms perform better than state firms because they were simply better firms to begin with (and were perhaps privatized for this reason) -- is an important element of our argument that privatization leads in short order to dramatic improvements in performance. To evaluate the presence of selection bias, we test for the equivalence of the pre-privatization performance of sample firms; to verify the subsequent divergence of performance, we apply the same test to the post-privatization data. Both tests involve re-estimation of equation (1) for those firms only for which complete pre- and postprivatization data are available. This allows us to determine whether the same privatized firms that were outperforming state firms after privatization were also outperforming the same state firms prior to privatization. $^{70}$

${ }^{70}$ The tests rely on a substantially smaller number of firms: in comparing the pre- and post-privatization performance of the same firms, we can use only firms privatized in 1991 and 1992 (since we had not asked for preprivatization data for firms privatized in 1990) and, among those, only firms that provided data on both pre- and postprivatization performance. The small number of such firms (10 firms privatized in 1991 and 19 firms privatized in 1992) necessitates grouping of the two "vintages." This, in turn, creates a problem of choosing the demarcation line between the pre- and post-privatization periods for the entire group. In the event, we decided to use 1990-91 as the pre-privatization period and 1992-93 as the post-privatization period, with 1991-92 excluded from the equations. If anything, our choice tilts the results in favor of the selection bias hypothesis. Given the already observed quick impact of privatization, one would expect privatized firms to improve their performance somewhat in the year of privatization. Hence, including 1991 in the preprivatization period for firms privatized in 1991 tends to inflate their pre-privatization performance. On the other hand, counting 1992 as a post-privatization year for firms privatized in 1992 tends to deflate the post-privatization performance, as it discounts the expected 1992 improvement of performance of these firms. 
To verify that state and privatized firms were in a similar initial "shape," we assessed the excess of revenues over variable costs (labor and materials.) Within the limits of our data, a higher excess is likely to identify a firm that has a better product, enabling it to keep a greater portion of its market at the time when revenues of other firms dramatically decline as a result of the transition effect. Table 5 below reports the initial share of costs in annual revenues for various types of owners.

Note that insider-owned firms had markedly lower initial values of labor and material costs per unit of revenue than state firms; if our conjecture is correct, then some owners of privatized firms, namely corporate insiders of the privatized enterprises, seem to be getting consistently better than average firms, while others, primarily privatization funds, are getting worse ones. This kind of selection bias, though it may very well exist, cannot be viewed as responsible for the superior postprivatization performance of privatized firms after privatization.

TABLE 5 INITIAL POSITION OF PRIVATIZED AND STATE FIRMS

\begin{tabular}{l|l||c|c|}
\cline { 2 - 3 } \multicolumn{1}{|c||}{ Largest owner } & $\begin{array}{c}\text { Average labor and } \\
\text { material costs } \\
\text { per unit of revenue } \\
\text { in the initial year* }\end{array}$ & $\begin{array}{c}\text { Average labor and } \\
\text { material costs } \\
\text { per unit of revenue } \\
\text { in subsequent years }\end{array}$ \\
\hline \hline Foreign company & $94 \%$ & $88 \%$ \\
Privatization fund & $102 \%$ & $96 \%$ \\
Domestic nonfinancial company & $85 \%$ & $95 \%$ \\
Individual shareholder & $84 \%$ & $74 \%$ \\
Managers & $61 \%$ & $77 \%$ \\
Non-managerial employees & $73 \%$ & $87 \%$ \\
State or state-owned company & $99 \%$ & $92 \%$ \\
State enterprises & $90 \%$ & \\
\hline * For state firms, 1990 or first year for which data are available; for privatized firms, the year of privatization
\end{tabular}

But the most striking feature of Table 5 is that firms controlled by insiders not only had, on average, considerably lower initial values of labor and material costs per unit of revenue, but that they also increased those costs after privatization, while groups of privatized firms with outsider owners managed over the same period to reduce the high share of labor and material costs inherited from the past. This suggests that if any selection bias exists in our sample, it is a negative selection bias that handicaps the impact of privatization.

We therefore estimated the pre- and post-privatization performance of the same set of state and privatized firms twice - with and without insider-owned firms. The results are summarized in Table 6 below (full regression statistics are in Table A.3, Appendix A).

TABLE 6 PRE- AND POST-PRIVATIZATION PERFORMANCE 


\begin{tabular}{|c|c|c|}
\hline \multirow{2}{*}{ Privatized firms } & \multicolumn{2}{|c|}{ Performance contrast with state firms } \\
\hline & prior to privatization & following privatization \\
\hline \multicolumn{3}{|l|}{ Revenue growth } \\
\hline with insider-owned firms & $8.54 * *$ & $11.24 *$ \\
\hline without insider-owned firms & 6.56 & $11.88^{*}$ \\
\hline \multicolumn{3}{|l|}{ Labor productivity growth } \\
\hline with insider-owned firms & 2.87 & $9.66^{* *}$ \\
\hline without insider-owned firms & 0.64 & $15.60 *$ \\
\hline
\end{tabular}

$* \mathrm{p}<0.05 ; * * \mathrm{p}<0.10$

The results confirm our conjecture. When insider-owned firms are included, the pre-privatization performance difference with respect to state firms (the "pre-privatization effect"), slightly above $8.5 \%$, is significant (if only at $\mathrm{p}=0.09$.) Even then, though, not only is the pre-privatization regression devoid of any significant explanatory power, but the initial size effect, invariably significant in all post-privatization regression, lacks significance as well. In a marked contrast, the post-privatization regression explains a significant portion of the performance of sample firms, with both the privatization effect and the initial size component of the transition effect significantly different from zero. ${ }^{71}$

When the insider-owned firms are excluded from the pre- and post-privatization performance comparisons, the "pre-privatization effect" drops to $6.56 \%$ and loses statistical significance while the post-privatization difference increases to nearly $12 \%$ and remains significant. Productivity performance strengthens the evidence provided by revenue contrasts. The preprivatization estimates fail to differentiate between privatized and state firms regardless of whether insider-owned firms are included or excluded, while the post-privatization results confirm a strong and significant performance improvement, with the performance contrast increasing from

71 The estimates of the privatization effect over 1992-1993 period reported here are somewhat weaker than those reported previously. As between the two, the estimates based on longer time periods and more firms are more indicative of the true difference made by privatization. The role of the estimates of post-privatization performance in this section, however, is not to achieve precise measurements of long-term privatization effects, but to show that our equation is sufficiently sensitive to pick up even short-term performance differences among the smaller group of firms. What the significance of the privatization effect in the postprivatization period shows, therefore, is that the absence of significant differences in the preprivatization period is not a function of a weak explanatory power of our equation, but rather an indication that the performance of the two groups of firms prior to privatization is indeed not significantly different. 
2.87 to 9.66 when insider-owned firm are included and from 0.64 to 15.60 when they are excluded.

Thus, insider-owned firms (and employee-owned ones in particular) tend to dissipate any initial advantages they may have and do not perform significantly better than state companies after privatization. This suggests the presence of a negative selection bias which handicaps the impact of privatization: the insiders -- employees in particular -- tend to acquire better firms only to fritter their advantages away. It is the outsider owners who tend to get worse than average firms, that reach the greatest strides in terms of later revenue performance

The above results provide not only strong evidence against any selection bias favoring privatized firms, but also testify against the presence of another factor that could perhaps make selection bias more difficult to detect. It is sometimes argued that insiders (in particular managers) purposefully undertake to lower the value of a firm prior to its privatization to be able to acquire it later on better terms -- a behavior that would make privatized firms look less attractive prior to privatization and thus hide the phenomenon of selection bias. In our sample, however, insiderowned firms actually have higher pre-privatization performance than other firms to be privatized, thus arguing against any moral hazard hypothesis.

\section{CONCLUDING REMARKS}

The importance of privatization for the success of the postcommunist reforms has been a subject of some controversy. Early in the reform period, some assumed that macroeconomic stabilization -- budgetary discipline, low inflation, price and trade liberalization, and hard budget constraints for enterprises -- would create a sufficiently competitive environment for most viable enterprises to restructure and for others to shrink or go out of business. The impact of ownership on the performance of large enterprises (in which ownership and management tend to be separated) was also sometimes believed to be quite attenuated, so as to make managerial reforms more important than rapid privatization, and the strength of the postcommunist economies was expected to come primarily from smaller, new businesses. A number of observers in fact believed that devoting too much resources and attention to rapid privatization carried a danger of creating "phony owners" and distracting from the more important task of fostering startup investments. ${ }^{72}$ Others, and much public opinion in Central and Eastern Europe, feared that rapid privatization would lead to serious dislocations, including high unemployment, and cause many potentially viable enterprises to go bankrupt.

Our findings provide strong empirical evidence that private ownership dramatically improves the most essential aspects of corporate performance in the countries undergoing

\footnotetext{
72 Kornai (1990), Murrell (1992). Although the present study does not speak directly to the question of the relative importance of privatized versus startup businesses for the overall success of the postcommunist economies, our results do show that new private businesses are the most dynamic enterprises in Central Europe.
} 
postcommunist transition. In particular:

1. we find no evidence any "privatization shock" which afflicts the behavior of the firms undergoing rapid ownership change. On the contrary, what we observe is a severe shock of marketization, which affects the performance of both state and privatized firms, and to which privatization provides a powerful antidote;

b. we find no evidence that privatization adds to the social dislocations of the transition process. On the contrary, our data indicate that once the system of pervasive subsidization is stopped or significantly reduced and the macroeconomic reforms are in place, privatization is the dominant employment strategy in transition

The paper also provides empirical evidence of considerable import for privatization policies. In particular:

3. we find that outsider-owned firms perform better that insider-owned firms on most performance measures. There are, however, enough differences between employee-owned and manager-owned firms to suggest that the common practice of putting all insiders under a common umbrella is unjustified. While the effects of managerial ownership are ambiguous, putting employees in control appears to offer no advantages over state ownership on any performance measure, and to bring a distinct disadvantage to employment performance;

4. among outsider owners, we find considerable evidence that privatization funds do as well at revitalizing the privatized companies as other outsider owners; in particular, we find no evidence that they are less effective than "strategic" investors. We also find that foreign investors provide perhaps less of an edge than might have been expected; in particular, their impact appears no stronger than that of major domestic outsiders

But teasing out the effects of ownership-driven restructuring from the general "noise" of transition and the restructuring driven by new market pressures, as we have done here, opens a host of other important questions. All types of firms in transition reduce the bloated employment of the past, all must look for new markets once the old captive customers are gone, all try to improve their previously shoddy products, and all have to cut down on the incredibly wasteful uses of energy and materials. As a result, to examine the impact of ownership we must look not only into whether firms are restructuring, but how. Our paper provides strong evidence that private owners restructure more effectively than the state. But what is it that makes their restructuring more successful? Are they more focused in their priorities? Are they better able to cope with the risks inherent in business activity? Are they better in dealing with an uncertain future or more adept at reacting to the past? Are they subject to greater financial discipline? Can we isolate certain types of restructuring that depend on the presence of owners from those that do not? We attempt to answer these questions in companion papers, where we examine the ways privatized and state firms restructure their operations, react to competitive pressures, evaluate managerial performance, and discipline their finances. 


\section{REFERENCES}

Balcerowicz, L., C.W. Gray, and I. Hashi. 1997 (forthcoming.) Exit Processes in Transition Economies: Downsizing, Workouts, and Liquidation . Budapest: Central European University Press.

Blanchard, O., S. Commander, and F. Coricelli. 1994. Unemployment and Restructuring in Eastern Europe. Mimeo.

Boardman, A.E. and A.R. Vining, 1989. "Ownership and Performance in Competitive Environments: A Comparison of the Performance of Private, Mixed, and State-Owned Enterprises." Journal of Law and Economics 32: 1-33

Caves, R.E. 1990. "Lessons from Privatization in Britain: State Enterprise Behavior, Public Choice, and Corporate Governance." Journal of Economic Behavior and Organization 13: 145-169

Claessens, S,. S. Djankov, and G. Pohl. 1997a. "Determinants of Performance of Manufacturing Firms in Seven European Transition Economies." Mimeo.

Claessens, S., S. Djankov, and G. Pohl. 1997b. "Ownership and Corporate Governance: Evidence from the Czech Republic." World Bank Policy Research Working Paper 1737, Washington, D.C.: The World Bank.

Coffee, J.C.. 1966. “Institutional Investors in Transitional Economies,” in Frydman, R., C.W. Gray, and A. Rapaczynski, eds. Corporate Governance in Central Europe and Russia . Volume 1: Banks, Funds, and Foreign Investors. Budapest: Central European University Press.

De Alessi, L. 1980. "The Economics of Property Rights: A Review of the Evidence." Research in Law and Economics, vol. 2: 1-47.

Demsetz, H. and K. Lehn. 1985. "The Structure of Corporate Ownership: Causes and Consequences." Journal of Political Economy. vol. 93 (6): 1155-77.

Djankov, S. and G. Pohl. 1997. "Restructuring of Large Firms in Slovakia." World Bank Working Paper 1758.

Earle , J.S. and S. Estrin. 1996. "Employee Ownership in Transition," in Frydman, R., C.W. Gray, and A. Rapaczynski, eds. Corporate Governance in Central Europe and Russia . Volume 2: Insiders and the State. Budapest: Central European University Press.

Earle, J., R. Frydman, A. Rapaczynski, and J. Turkewitz (1994), Small Privatization; The Transformation of Retail Trade and Consumer Services in the Czech Republic, Hungary, and Poland Budapest: Central European University Press

Frydman, R., E.S.. Phelps, A. Rapaczynski, and A. Shleifer. 1993. "Needed Mechanisms of Corporate Governance and Finance in the Economic Reform of Eastern Europe." Economics of Transition 1: 171-207.

Frydman, R., A. Rapaczynski, and J. Turkewitz. 1997. "Transition to a Private Property Regime in the Czech Republic and Hungary," in Parker, S., Sachs, J. and W. Woo, eds. Comparing Transition Economies in Central Europe and Asia. Cambridge, MA: MIT Press

.Frydman, R. and A. Rapaczynski. 1994. Privatization in Eastern Europe: Is the State Withering Away? Budapest: Central European University Press

Galal A., L Jones, P.Tandon and I. Vogelsangl.1994. Welfare Consequences of Selling Private Enterprises . Oxford: Oxford University Press.

Hansmann, H. 1996. The Ownership of Enterprise. New York: Belknap Press.

Kollo, J. "Short-term response of Employment to Sales in State-Owned and Private Firms in Hungary 19901994." Mimeo.

Kornai, J. 1990. The Road to a Free Economy. Shifting from a Socialist System: The Example of Hungary. New York: W.W.Norton

Kornai, J. 1992. The Socialist System. The Political Economy of Communism. Princeton: Princeton 
University Press.

Lieberman, I. and John Nellis, eds. 1994. Russia: Creating Private Enterprise and Efficient Markets. Washington, D.C.: The World Bank.

Megginson, W. L., R. C., Nash, and M. van Randenborgh. 1994. “The Financial and Operating Performance of Newly Privatized Firms: An International Empirical Analysis" Journal of Finance, XLIX, no. 2, June.

Murrell, P. 1992. "Privatization versus the Fresh Start." in Tismaneanu, V. and P. Clawson. Uprooting Leninism, Cultivating Liberty. Philadelphia: University Press of America.

Pinto, B., M. Belka, and S. Krajewski. 1993. "Transforming State Enterprises in Poland: Evidence on Adjustment By Manufacturing Firms.” Brookings Papers on Economic Activity, 1: 213-269.

Pinto, B. and S. van Wijnbergen,. 1994. "Ownership and Corporate Control in Poland: Why State Firms Defied the Odds." World Bank Working Paper 1308.

Pistor, K. and J. Turkewitz. 1996. "Coping with Hydra: State Ownership After Privatization. A Comparative Study of of Hungary, Russia, and the Czech Republic." In Frydman, R., C.Gray, and A. Rapaczynski, eds. Corporate Governance in Central Europe and Russia . Vol.2, Budapest: Central European University Press.

Pohl G., Anderson, R.E., Claessens, S. and S. Djankov. 1997. "Privatization and Restructuring in Central and Eastern Europe." World Bank Technical Paper no. 368

Roland G. 1995. "Political Economy Issues of Ownership Transformation in Eastern Europe," in Aoki, M. and H. Kim, eds. Corporate Governance in Transitional Economies. EDI Development Studies, Washington, D.C.: The World Bank.

Shleifer, A. and D. Vasiliev. 1996. "Management Ownership and Russian Privatization." In Frydman, R., Gray, C., and A. Rapaczynski, eds. Corporate Governance in Central Europe and Russia . Vol.2, Budapest: Central European University Press.

Vickers, J. and G. Yarrow.1986. "Telecommunications: Liberalization and the Privatization of British Telecom." In Kay, J., Mayer, C. and D. Thompson, eds. Privatization and Regulation. Oxford: Oxford University Press.

Vickers, J. and G.Yarrow.1988. Privatization: an Economic Analysis . Cambridge: MIT Press

White, H. 1980. "A Heteroscedasticity-Consistent Covariance Matrix Estimator and a Direct Test for Heteroscedasticity." Econometrica 48: 817-838 


\title{
APPENDIX A. REGRESSION STATISTICS
}

\author{
LIST OF REGRESSION VARIABLES
}

\section{DEPENDENT VARIABLE: PERFORMANCE MEASURE (ARGPERF)}

For privatized firms, growth of all performance measures is annualized between the year of privatization and end-1993; for state firms, the growth is annualized between 1990-93, 1991-93 and 1992-93, producing three sets of estimates for each performance measure.

REVENUES: annualized rate of revenue growth. Revenues measured in constant local prices. EMPLOYMENT: annualized rate of employment growth.

LABOR PRODUCTIVITY: annualized rate of growth of revenue per employee. Revenues measured in constant local prices.

COST: annualized rate of growth of labor and material costs per unit of revenue. Revenues and labor and material costs measured in constant local prices.

\section{INDEPENDENT VARIABLES}

INIPERF: $\quad$ the initial value of performance measure. For privatized firms, the initial value corresponds to the year of privatization; for state firms, the initial value corresponds to 1990 or first year for which data is available.) Initial revenue is measured in US\$1,000,000's, initial employment in 100 's full-time employee, and initial labor productivity in US\$1,000's per full-time employee.

\footnotetext{
$P R V \quad=1$ if the firm is privatized, 0 otherwise

OUTSDR $\quad=1$ If the largest owner is an outsider (not an employee of the firm), 0 otherwise

INSDR $\quad=1$ If the largest owner is an inside (an employee of the firm), 0 otherwise

FRGN $\quad=1$ If the largest owner is a foreign company, 0 otherwise

PRVFND $\quad=1$ if the largest owner is a privatization fund, 0 otherwise

$D M N F I N=1$ if the largest owner is a private domestic non-financial company, 0 bierwise

INDIV $\quad=1$ if the largest owner is a domestic individual shareholder, 0 otherwise

$M N G R S=1$ if the largest owner is management, 0 otherwise

EMPLS $\quad=1$ if the largest owner are non-managerial employees, 0 otherwise

STATE $\quad=1$ if the largest owner isstate or state-owned company, 0 otherwise

$\mathrm{HU} \quad=1$ If the firm is in Hungary, 0 otherwise

$P L \quad=1$ If the firm is in Poland, 0 otherwise
} 
TABLE A.1 PERFORMANCE EQUATIONS

\begin{tabular}{|c|c|c|c|c|}
\hline & REVENUE GROWTH & EMPLOYMENT & REVENUE/EMPLOYEE & COST/REVENUE \\
\hline (1) & ARGPERF & $a+a_{0}$ INIPERF & $+\beta P R V+e$ & \\
\hline CONST & $\begin{array}{r}-15.82^{*} \\
(1.92)\end{array}$ & $\begin{array}{l}-7.47^{\star} \\
(1.20)\end{array}$ & $\begin{array}{l}-5.21^{*} \\
(2.01)\end{array}$ & $\begin{array}{l}30.06^{*} \\
(4.16)\end{array}$ \\
\hline INIPERF & $\begin{array}{c}-0.25^{\star} \\
(0.06)\end{array}$ & $\begin{array}{l}-0.40^{*} \\
(0.10)\end{array}$ & $\begin{array}{l}-0.28^{*} \\
(0.06)\end{array}$ & $\begin{array}{l}-0.31^{*} \\
(0.05)\end{array}$ \\
\hline \multirow[t]{2}{*}{ PRV } & $\begin{array}{r}19.01^{*} \\
(3.18)\end{array}$ & $\begin{array}{l}\mathbf{5 . 8 8}^{*} \\
(1.61)\end{array}$ & $\begin{array}{r}\mathbf{1 1 . 1 7}^{*} \\
(3.21)\end{array}$ & $\begin{array}{l}-3.00 \\
(2.28)\end{array}$ \\
\hline & $\begin{array}{c}n=179 \\
F=23.78^{\star} \\
\text { adj. } R^{2}=0.20\end{array}$ & $\begin{array}{c}n=169 \\
F=13.74^{*} \\
\text { adj. } R^{2}=0.13\end{array}$ & $\begin{array}{c}n=162 \\
F=12.59^{\star} \\
\text { adj. } R^{2}=0.13\end{array}$ & $\begin{array}{c}\mathrm{n}=135 \\
\mathrm{~F}=24.33^{\star} \\
\text { adj. } \mathrm{R}^{2}=0.26\end{array}$ \\
\hline
\end{tabular}

(2a) ARGPERF $=a+a_{0}$ INIPERF $+\beta_{1}$ OUTSDR $+\beta_{2}$ INSDR $+?_{1} H U+?_{2} P L+e$

\begin{tabular}{|c|c|c|c|c|}
\hline CONST & $\begin{array}{l}-9.84^{*} \\
(3.73)\end{array}$ & $\begin{array}{l}-6.87^{*} \\
(2.13)\end{array}$ & $\begin{array}{l}-5.00 \\
(3.53)\end{array}$ & $\begin{array}{c}35.84^{*} \\
(5.30)\end{array}$ \\
\hline INIPERF & $\begin{array}{l}-0.27^{\star} \\
(0.08)\end{array}$ & $\begin{array}{l}-0.34^{\star} \\
(0.12)\end{array}$ & $\begin{array}{l}-0.30^{\star} \\
(0.07)\end{array}$ & $\begin{array}{l}-0.30^{\star} \\
(0.05)\end{array}$ \\
\hline OUTSDR & $\begin{array}{r}1^{18.19^{*}} \\
(3.66)\end{array}$ & $\begin{array}{l}\text { 4.08* } \\
(1.87)\end{array}$ & $\begin{array}{r}12.79^{*} \\
(3.47)\end{array}$ & $\begin{array}{l}-5.37^{\star *} \\
(2.28)\end{array}$ \\
\hline INSDR & $\begin{array}{r}14.52^{*} \\
(5.99)\end{array}$ & $\begin{array}{l}10.59^{*} \\
(3.12)\end{array}$ & $\begin{array}{c}0.63 \\
(5.65)\end{array}$ & $\begin{array}{c}2.17 \\
(4.39)\end{array}$ \\
\hline$H U$ & $\begin{array}{l}-6.89^{* *} \\
(3.77)\end{array}$ & $\begin{array}{l}-0.43 \\
(2.02)\end{array}$ & $\begin{array}{c}2.86 \\
(3.67)\end{array}$ & $\begin{array}{r}-10.57^{*} \\
(2.82)\end{array}$ \\
\hline \multirow[t]{2}{*}{$P L$} & $\begin{array}{l}-8.05^{\star *} \\
(4.44)\end{array}$ & $\begin{array}{l}-2.07 \\
(2.23)\end{array}$ & $\begin{array}{l}-1.19 \\
(4.10)\end{array}$ & $\begin{array}{l}-6.23^{* *} \\
(3.41)\end{array}$ \\
\hline & $\begin{array}{c}n=178 \\
F=10.97^{\star} \\
\text { adj. } R^{2}=0.22\end{array}$ & $\begin{array}{c}n=168 \\
F=6.55^{*} \\
\text { adj. } R^{2}=0.14\end{array}$ & $\begin{array}{c}\mathrm{n}=161 \\
\mathrm{~F}=6.17^{\star} \\
\text { adj. } \mathrm{R}^{2}=0.14\end{array}$ & $\begin{array}{c}n=134 \\
F=13.66^{*} \\
\text { adj. } R^{2}=0.32\end{array}$ \\
\hline
\end{tabular}

(2b) ARGPERF $=a+a_{0}$ INIPERF $+S_{i} \beta_{i}$ OWNR $+?_{1} H U+?_{2} P L+e$

\begin{tabular}{|c|c|c|c|c|}
\hline CONST & $\begin{array}{c}-12.14^{\star} \\
(3.37)\end{array}$ & $\begin{array}{l}-6.03^{*} \\
(1.90)\end{array}$ & $\begin{array}{l}-6.21^{\star \star} \\
(3.25)\end{array}$ & $\begin{array}{c}35.99^{*} \\
(5.49)\end{array}$ \\
\hline INIPERF & $\begin{array}{r}-0.26^{*} \\
(0.08)\end{array}$ & $\begin{array}{l}-0.35^{*} \\
(0.10)\end{array}$ & $\begin{array}{l}-0.31^{*} \\
(0.07)\end{array}$ & $\begin{array}{c}-0.31^{*} \\
(0.05)\end{array}$ \\
\hline FRGN & $\begin{array}{c}\mathbf{1 8 . 8 4}^{*} \\
(4.94)\end{array}$ & $\begin{array}{r}7.26^{*} \\
(2.13)\end{array}$ & $\begin{array}{l}8.29^{* *} \\
(4.77)\end{array}$ & $\begin{array}{c}-3.16 \\
(3.27)\end{array}$ \\
\hline PRVFND & 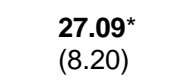 & $\begin{array}{c}0.96 \\
(3.69)\end{array}$ & $\begin{array}{l}16.25^{*} \\
(7.64)\end{array}$ & $\begin{array}{l}-5.23 \\
(5.62)\end{array}$ \\
\hline DMNFIN & $\begin{array}{l}8.54^{* *} \\
(4.95)\end{array}$ & $\begin{array}{c}3.99 \\
(3.46)\end{array}$ & $\begin{array}{c}\mathbf{1 1 . 2 0}^{*} \\
(5.15)\end{array}$ & $\begin{array}{l}2.86 \\
(4.18)\end{array}$ \\
\hline INDIV & $\begin{array}{c}16.61^{*} \\
(4.79)\end{array}$ & $\begin{array}{c}3.10 \\
(7.57)\end{array}$ & $\begin{array}{c}19.32 \\
(16.89)\end{array}$ & $\begin{array}{c}-18.07^{*} \\
(6.99)\end{array}$ \\
\hline MNGRS & $\begin{array}{r}\mathbf{2 5 . 1 4}^{\star} \\
(12.52)\end{array}$ & $\begin{array}{r}6.86^{\star} \\
(2.68)\end{array}$ & $\begin{array}{c}11.39 \\
(11.51)\end{array}$ & $\begin{array}{c}4.98 \\
(7.61)\end{array}$ \\
\hline EMPLS & $\begin{array}{c}4.65 \\
(5.13)\end{array}$ & $\begin{array}{l}13.76^{*} \\
(5.19)\end{array}$ & $\begin{array}{l}-7.76 \\
(5.19)\end{array}$ & $\begin{array}{c}0.18 \\
(5.69)\end{array}$ \\
\hline STATE & $\begin{array}{l}15.88^{*} \\
(7.62)\end{array}$ & $\begin{array}{c}1.42 \\
(3.07)\end{array}$ & $\begin{array}{l}17.61^{*} \\
(8.25)\end{array}$ & $\begin{array}{l}-5.70^{\star \star} \\
(3.50)\end{array}$ \\
\hline$H U$ & $\begin{array}{l}-3.64 \\
(4.21)\end{array}$ & $\begin{array}{c}-1.82 \\
(1.77)\end{array}$ & $\begin{array}{c}5.60 \\
(4.00)\end{array}$ & $\begin{array}{r}-10.47^{\star} \\
(3.03)\end{array}$ \\
\hline \multirow[t]{2}{*}{$P L$} & $\begin{array}{l}-5.39 \\
(3.71)\end{array}$ & $\begin{array}{l}-2.79 \\
(2.27)\end{array}$ & $\begin{array}{c}0.19 \\
(4.01)\end{array}$ & $\begin{array}{l}-6.18^{*} \\
(2.94)\end{array}$ \\
\hline & $\begin{array}{c}\mathrm{n}=178 \\
\mathrm{~F}=6.39^{*} \\
\text { adj. } \mathrm{R}^{2}=0.23\end{array}$ & $\begin{array}{c}n=168 \\
F=3.82^{*} \\
\text { adj. } R^{2}=0.14\end{array}$ & $\begin{array}{c}n=161 \\
F=3.74^{\star} \\
\text { adj. } R^{2}=0.15\end{array}$ & $\begin{array}{c}n=134 \\
F=7.82^{*} \\
\text { adj. } R^{2}=0.34\end{array}$ \\
\hline
\end{tabular}


${ }^{*} p \leq 0.05,{ }^{* *} p \leq 0.10$; standard errors in parenthesis, significant coefficients bold-faced 
TABLE A.2 PERFORMANCE EQUATIONS

\begin{tabular}{|c|c|c|c|c|c|c|c|c|}
\hline & \multicolumn{4}{|c|}{ Performance of state firm 199 qLlygted over } & \multicolumn{2}{|c|}{$1992-93$} & \multirow[b]{2}{*}{$\begin{array}{l}\text { REVENUE/ } \\
\text { EMPLOYEE }\end{array}$} & \multirow[b]{2}{*}{$\begin{array}{c}\text { COST/ } \\
\text { REVENUI }\end{array}$} \\
\hline & REVENUE & $\begin{array}{l}\text { EMPLOY- } \\
\text { MENT }\end{array}$ & $\begin{array}{l}\text { REVENUE/ } \\
\text { EMPLOYEE }\end{array}$ & $\begin{array}{c}\text { COST/ } \\
\text { REVENUE }\end{array}$ & REVENUE & $\begin{array}{l}\text { EMPLOY- } \\
\text { MENT }\end{array}$ & & \\
\hline (1) & \multicolumn{8}{|c|}{ ARGPERF $=a+a_{0} I N I P E R F+\beta P R V+e$} \\
\hline CONST & $\begin{array}{r}-12.61^{*} \\
(2.23)\end{array}$ & $\begin{array}{l}-7.67^{\star} \\
(1.32)\end{array}$ & $\begin{array}{r}-1.00 \\
2.27\end{array}$ & $\begin{array}{l}29.89 \text { * } \\
(4.57)\end{array}$ & $\begin{array}{r}-14.93^{*} \\
(2.49)\end{array}$ & $\begin{array}{c}-5.77^{\star} \\
1.53\end{array}$ & $\begin{array}{l}-5.93^{*} \\
(2.53)\end{array}$ & $\begin{array}{l}30.60^{\star} \\
(4.70)\end{array}$ \\
\hline INIPERF & $\begin{array}{l}-0.26^{\star} \\
(0.06)\end{array}$ & $\begin{array}{l}-0.48^{\star} \\
(0.11)\end{array}$ & $\begin{array}{l}-0.29^{\star} \\
(0.06)\end{array}$ & $\begin{array}{l}-0.30^{*} \\
(0.05)\end{array}$ & $\begin{array}{l}-0.23^{*} \\
(0.06)\end{array}$ & $\begin{array}{l}-0.44^{\star} \\
(0.13)\end{array}$ & $\begin{array}{l}-0.24^{*} \\
(0.06)\end{array}$ & $\begin{array}{l}-0.30^{\star} \\
(0.05)\end{array}$ \\
\hline \multirow[t]{2}{*}{$P R V$} & $\begin{array}{r}15.87^{*} \\
(3.32)\end{array}$ & $\begin{array}{c}6.64^{*} \\
(1.68)\end{array}$ & $\begin{array}{c}7.15^{\star} \\
(3.34)\end{array}$ & $\begin{array}{l}-3.42 \\
(2.40)\end{array}$ & $\begin{array}{r}17.79 * \\
(3.47)\end{array}$ & $\begin{array}{r}\mathbf{4 . 4 3}^{\star} \\
(1.79)\end{array}$ & $\begin{array}{r}10.99^{\star} \\
(3.53)\end{array}$ & $\begin{array}{l}-4.47^{* *} \\
(2.49)\end{array}$ \\
\hline & $\begin{array}{l}n=179 \\
F=16.87^{*} \\
R^{2}=0.15\end{array}$ & $\begin{array}{l}n=169 \\
F=16.94^{*} \\
R^{2}=0.16\end{array}$ & $\begin{array}{l}n=162 \\
F=8.65^{\star} \\
R^{2}=0.09\end{array}$ & $\begin{array}{l}n=135 \\
F=21.65^{*} \\
R^{2}=0.24\end{array}$ & $\begin{array}{l}\mathrm{n}=179 \\
\mathrm{~F}=17.03^{*} \\
\mathrm{R}^{2}=0.15\end{array}$ & $\begin{array}{l}n=169 \\
F=9.29^{*} \\
R^{2}=0.15\end{array}$ & $\begin{array}{l}\mathrm{n}=162 \\
\mathrm{~F}=8.47^{\star} \\
\mathrm{R}^{2}=0.08\end{array}$ & $\begin{array}{l}\mathrm{n}=135 \\
\mathrm{~F}=21.65^{\star} \\
\mathrm{R}^{2}=0.24\end{array}$ \\
\hline (2) & \multicolumn{2}{|c|}{$A R G P E R F=a$} & $+a_{0} I N I P E$ & $F+S_{i} \beta_{i} C$ & $N N R_{i}+$ & $H U+? 2$ & $+e$ & \\
\hline CONST & $\begin{array}{l}-8.78^{*} \\
(3.70)\end{array}$ & $\begin{array}{l}-7.13^{*} \\
(2.00)\end{array}$ & $\begin{array}{l}-0.61 \\
(3.56)\end{array}$ & $\begin{array}{l}34.37^{*} \\
(6.50)\end{array}$ & $\begin{array}{r}-11.10^{*} \\
(3.73)\end{array}$ & $\begin{array}{l}-3.55 \\
(2.42)\end{array}$ & $\begin{array}{l}-6.67 * * \\
(3.82)\end{array}$ & $\begin{array}{c}33.64^{\star} \\
(6.70)\end{array}$ \\
\hline INIPERF & $\begin{array}{l}-0.27^{*} \\
(0.07)\end{array}$ & $\begin{array}{c}-0.43^{\star} \\
(0.11)\end{array}$ & $\begin{array}{l}-0.33^{*} \\
(0.07)\end{array}$ & $\begin{array}{l}-0.29^{*} \\
(0.00)\end{array}$ & $\begin{array}{l}-0.24^{*} \\
(0.07)\end{array}$ & $\begin{array}{l}-0.42^{*} \\
(0.14)\end{array}$ & $\begin{array}{l}\mathbf{- 0 . 2 9} * \\
(0.07)\end{array}$ & $\begin{array}{l}-0.28^{\star} \\
(0.06)\end{array}$ \\
\hline FRGN & $\begin{array}{l}\mathbf{1 5 . 1 8}^{*} \\
(5.20)\end{array}$ & $\begin{array}{c}8.65^{\star} \\
(2.20)\end{array}$ & $\begin{array}{c}3.73 \\
(4.96)\end{array}$ & $\begin{array}{l}-3.48 \\
(3.53)\end{array}$ & $\begin{array}{l}17.16^{*} \\
(5.17)\end{array}$ & $\begin{array}{c}6.89^{*} \\
(2.38)\end{array}$ & $\begin{array}{c}6.78 \\
(4.88)\end{array}$ & $\begin{array}{l}-3.11 \\
(3.52)\end{array}$ \\
\hline PRVFND & $\begin{array}{l}\text { 23.86* } \\
(8.30)\end{array}$ & $\begin{array}{c}2.84 \\
(3.79)\end{array}$ & $\begin{array}{l}10.91 \\
(7.75)\end{array}$ & $\begin{array}{l}-4.64 \\
(5.80)\end{array}$ & $\begin{array}{l}\text { 23.86* } \\
(8.30)\end{array}$ & $\begin{array}{l}-0.87 \\
(4.02)\end{array}$ & $\begin{array}{r}\text { 16.28* } \\
(7.92)\end{array}$ & $\begin{array}{l}-5.01 \\
(5.84)\end{array}$ \\
\hline$D M N F I N$ & $\begin{array}{c}5.33 \\
(5.11)\end{array}$ & $\begin{array}{l}5.67 \\
(3.51)\end{array}$ & $\begin{array}{c}6.93 \\
(5.28)\end{array}$ & $\begin{array}{c}2.93 \\
(4.20)\end{array}$ & $\begin{array}{c}7.10 \\
(5.10)\end{array}$ & $\begin{array}{c}2.93 \\
(3.63)\end{array}$ & $\begin{array}{l}\mathbf{1 0 . 6 3 *} \\
(5.23)\end{array}$ & $\begin{array}{l}2.56 \\
(3.62)\end{array}$ \\
\hline INDIV & $\begin{array}{l}13.10^{\star} \\
(5.15)\end{array}$ & $\begin{array}{c}4.02 \\
(7.83)\end{array}$ & $\begin{array}{c}14.57 \\
(17.23)\end{array}$ & $\begin{array}{c}-18.00^{\star} \\
(6.98)\end{array}$ & $\begin{array}{l}15.44^{*} \\
(5.14)\end{array}$ & $\begin{array}{c}1.71 \\
(7.89)\end{array}$ & $\begin{array}{c}18.99 \\
(17.49)\end{array}$ & $\begin{array}{c}-18.01^{*} \\
(7.34)\end{array}$ \\
\hline MNGRS & $\begin{array}{l}\mathbf{2 1 . 4 3}^{\star *} \\
(12.72)\end{array}$ & $\begin{array}{c}7.91^{*} \\
(2.78)\end{array}$ & $\begin{array}{c}6.52 \\
(11.54)\end{array}$ & $\begin{array}{l}5.53 \\
(7.83)\end{array}$ & $\begin{array}{l}23.77^{\star \star} \\
(12.69)\end{array}$ & $\begin{array}{c}5.99^{*} \\
(2.96)\end{array}$ & $\begin{array}{c}10.13 \\
(11.79)\end{array}$ & $\begin{array}{l}6.07 \\
(7.81)\end{array}$ \\
\hline EMPLS & $\begin{array}{c}0.59 \\
(5.59)\end{array}$ & $\begin{array}{c}14.90^{*} \\
(5.25)\end{array}$ & $\begin{array}{c}-12.25^{\star} \\
(5.52)\end{array}$ & $\begin{array}{l}-0.31 \\
(5.90)\end{array}$ & $\begin{array}{c}2.98 \\
(5.53)\end{array}$ & $\begin{array}{l}\text { 13.78* }^{*} \\
(5.35)\end{array}$ & $\begin{array}{r}-\mathbf{1 0 . 1 8 *} \\
(5.22)\end{array}$ & $\begin{array}{c}1.00 \\
(5.84)\end{array}$ \\
\hline STATE & $\begin{array}{c}12.38 \\
(7.79)\end{array}$ & $\begin{array}{c}2.80 \\
(3.13)\end{array}$ & $\begin{array}{l}13.25 \\
(8.41)\end{array}$ & $\begin{array}{l}-5.84 \\
(3.63)\end{array}$ & $\begin{array}{c}14.15^{\star *} \\
(7.80)\end{array}$ & $\begin{array}{c}0.72 \\
(3.17)\end{array}$ & $\begin{array}{c}\text { 15.91*** } \\
(8.60)\end{array}$ & $\begin{array}{l}-5.74 \\
(3.66)\end{array}$ \\
\hline$H U$ & $\begin{array}{l}-2.90 \\
(4.51)\end{array}$ & $\begin{array}{l}-1.54 \\
(1.89)\end{array}$ & $\begin{array}{c}4.84 \\
(4.28)\end{array}$ & $\begin{array}{l}-9.09^{\star} \\
(3.25)\end{array}$ & $\begin{array}{l}-3.14 \\
(4.50)\end{array}$ & $\begin{array}{l}-4.05^{\star *} \\
(2.19)\end{array}$ & $\begin{array}{l}\text { 7.92** } \\
(4.29)\end{array}$ & $\begin{array}{r}-10.46^{\star} \\
(3.23)\end{array}$ \\
\hline$P L$ & $\begin{array}{l}-6.09 \\
(3.97)\end{array}$ & $\begin{array}{l}-0.97 \\
(2.40)\end{array}$ & $\begin{array}{l}-2.05 \\
(4.33)\end{array}$ & $\begin{array}{l}-4.76 \\
(3.40)\end{array}$ & $\begin{array}{l}-6.00 \\
(4.40)\end{array}$ & $\begin{array}{l}-2.52 \\
(2.70)\end{array}$ & $\begin{array}{l}-1.23 \\
(4.87)\end{array}$ & $\begin{array}{l}-2.61 \\
(3.57)\end{array}$ \\
\hline & $\begin{array}{c}n=178 \\
F=4.81^{*} \\
R^{2}=0.18\end{array}$ & $\begin{array}{c}n=168 \\
F=4.14^{*} \\
R^{2}=0.16\end{array}$ & $\begin{array}{c}n=161 \\
F=2.84^{*} \\
R^{2}=0.10\end{array}$ & $\begin{array}{c}n=134 \\
F=6.57^{\star} \\
R^{2}=0.29\end{array}$ & $\begin{array}{c}n=178 \\
F=4.69^{*} \\
R^{2}=0.17\end{array}$ & $\begin{array}{c}n=168 \\
F=2.75^{*} \\
R^{2}=0.09\end{array}$ & $\begin{array}{c}n=161 \\
F=2.90^{*} \\
R^{2}=0.11\end{array}$ & $\begin{array}{c}n=134 \\
F=6.65^{*} \\
R^{2}=0.30\end{array}$ \\
\hline
\end{tabular}

${ }^{*} p \leq 0.05,{ }^{* *} p \leq 0.10$; standard errors in parenthesis, significant coefficients bold-faced 
TABLE A.3 PRE- AND POST-PRIVATIZATION PERFORMANCE EQUATIONS

(OLS regressions, White's adjustment for heteroscedasticity consistent estimates)

\begin{tabular}{|c|c|c|c|c|}
\hline \multirow{2}{*}{} & \multicolumn{2}{|c|}{ Revenue } & \multicolumn{2}{c|}{ Labor productivity } \\
\cline { 2 - 5 } & Pre-privatization: & Post-privatization: & Pre-privatization: & Post-privatization: \\
& $1990-91$ & $1992-93$ & $1990-91$ & $1992-93$ \\
\hline \hline
\end{tabular}

(1)

$A R G P E R F=a+a_{0} I N I P E R F+\beta P R V+e$

Without insider-owned firms

\begin{tabular}{|c|c|c|c|c|}
\hline CONST & $\begin{array}{c}29.14^{*} \\
3.01\end{array}$ & $\begin{array}{r}-13.75^{\star} \\
(3.92)\end{array}$ & $\begin{array}{c}-17.62^{*} \\
(4.65)\end{array}$ & $\begin{array}{l}-8.56^{\star} \\
(4.16)\end{array}$ \\
\hline INIPERF & $\begin{array}{l}-0.01 \\
0.08\end{array}$ & $\begin{array}{l}-0.21 \\
(0.08)\end{array}$ & $\begin{array}{l}-0.10 \\
(0.12)\end{array}$ & $\begin{array}{l}-0.17 \\
(0.15)\end{array}$ \\
\hline PRV & $\begin{array}{l}6.56 \\
6.18\end{array}$ & $\begin{array}{l}11.88^{*} \\
(6.04)\end{array}$ & $\begin{array}{c}0.64 \\
(6.63)\end{array}$ & $\begin{array}{l}15.60^{*} \\
(6.75)\end{array}$ \\
\hline & $\begin{array}{c}n=92 \\
F=0.76 \\
R^{2}=0.00\end{array}$ & $\begin{array}{c}n=92 \\
F=3.42^{*} \\
R^{2}=0.05\end{array}$ & $\begin{array}{c}n=86 \\
F=0.21 \\
R^{2}=-0.01\end{array}$ & $\begin{array}{c}n=86 \\
F=4.13 \\
R^{2}=0.07\end{array}$ \\
\hline
\end{tabular}

With insider-owned firms

\begin{tabular}{|l|cccc|}
\hline \multirow{2}{*}{ CONST } & $\mathbf{- 2 8 . 0 0 ^ { * }}$ & $-\mathbf{1 6 . 3 9 ^ { * }}$ & $\mathbf{- 1 7 . 5 7 ^ { * }}$ & $\mathbf{- 9 . 0 6 ^ { * }}$ \\
& $(2.91)$ & $(3.18)$ & $(4.35)$ & $(3.71)$ \\
& & & & -0.15 \\
INIPERF & -0.03 & $-0.17^{\star}$ & -0.10 & $(0.12)$ \\
& $(0.08)$ & $(0.07)$ & $(0.10)$ & $9.66^{\star *}$ \\
& & & & $(5.53)$ \\
& $8.54^{\star *}$ & $11.24^{\star}$ & 2.87 & $\mathrm{n}=95$ \\
& $(4.99)$ & $(4.80)$ & $(5.52)$ & $\mathrm{F}=2.34$ \\
& $\mathrm{n}=100$ & $\mathrm{n}=100$ & $\mathrm{n}=95$ & $\mathrm{R}^{2}=0.03$ \\
\hline
\end{tabular}

${ }^{*} p \leq 0.05,{ }^{* *} p \leq 0.10$

Standard errors in parenthesis, significant coefficients bold-faced 


\section{APPENDIX B. SAMPLE DESCRIPTIONS}

\section{B.1 COUNTRY DISTRIBUTION OF SAMPLE FIRMS}

\begin{tabular}{|c|c|c|c|c|}
\hline Firm type & Czech R & Hungary & Poland & All \\
\hline State firms & 23 & 27 & 43 & 93 \\
\hline Privatized firms & 43 & 46 & 6 & 95 \\
\hline privatized in $1990 *$ & - & 13 & 2 & 15 \\
\hline privatized in 1991 & 5 & 13 & 4 & 22 \\
\hline privatized in 1992 & 38 & 20 & - & 58 \\
\hline All & 65 & 73 & 49 & 185 \\
\hline
\end{tabular}

\section{B.2 OWNERSHIP STRUCTURE OF PRIVATIZED FIRMS}

\begin{tabular}{|c|c|c|}
\hline Shareholder & $\begin{array}{l}\text { Number of firms } \\
\text { in which shareholder } \\
\text { is the largest owner }\end{array}$ & $\begin{array}{l}\text { Mean holdings } \\
\text { when } \\
\text { the largest owner }\end{array}$ \\
\hline Foreign company & 27 & $92 \%$ \\
\hline Czech Republic & 8 & $60 \%$ \\
\hline Hungary & 18 & $84 \%$ \\
\hline Poland & 1 & $60 \%$ \\
\hline Privatization fund & 17 & $20 \%$ \\
\hline Czech Republic & 17 & $20 \%$ \\
\hline Domestic nonfinancial company & 9 & $64 \%$ \\
\hline Czech Republic & 5 & $73 \%$ \\
\hline Hungary & 2 & $77 \%$ \\
\hline Poland & 2 & $60 \%$ \\
\hline Domestic individual & 6 & $50 \%$ \\
\hline Czech Republic & 3 & $60 \%$ \\
\hline Hungary & 2 & $52 \%$ \\
\hline Poland & 1 & $60 \%$ \\
\hline State or state-owned company & 14 & $45 \%$ \\
\hline Czech Republic & 6 & $36 \%$ \\
\hline Hungary & 7 & $49 \%$ \\
\hline Poland & 1 & $60 \%$ \\
\hline Managerial employees & 9 & $67 \%$ \\
\hline Czech Republic & 4 & $88 \%$ \\
\hline Hungary & 5 & $67 \%$ \\
\hline Poland & . & - \\
\hline Non-managerial employees & 10 & $80 \%$ \\
\hline Hungary & 10 & $80 \%$ \\
\hline
\end{tabular}




\section{B.3 DISTRIBUTION OF INITIAL AND ENDING REVENUES AND EMPLOYMENT}

\begin{tabular}{|c|c|c|c|c|c|c|}
\hline \multirow[t]{2}{*}{ Firm type } & \multicolumn{3}{|c|}{$\begin{array}{l}\text { Initial / ending revenue } \\
\text { (US\$ mil, constant prices) }\end{array}$} & \multicolumn{3}{|c|}{$\begin{array}{l}\text { Initial / ending } \\
\text { employment }\end{array}$} \\
\hline & Firms & Mean & Median & Firms & Mean & Median \\
\hline \multicolumn{7}{|c|}{ ALL COUNTRIES } \\
\hline $\begin{array}{l}\text { State } \\
\text { Privatized } \\
\text { Old private } \\
\text { New private }\end{array}$ & $\begin{array}{l}93 \\
95 \\
19 \\
36\end{array}$ & $\begin{array}{r}15.01 / 10.74 \\
13.79 / 13.59 \\
7.02 / 9.76 \\
4.01 / 5.51\end{array}$ & $\begin{array}{l}6.56 / 5.51 \\
5.45 / 5.98 \\
1.12 / 5.52 \\
1.32 / 2.60\end{array}$ & $9 \mathrm{e}+07$ & $\begin{array}{l}785 \text { / } 563 \\
724 / 601 \\
197 / 225 \\
143 / 170\end{array}$ & $\begin{array}{c}541 / 393 \\
379 / 340 \\
93 / 142 \\
88 / 140\end{array}$ \\
\hline \multicolumn{7}{|c|}{ CZECH REPUBLIC } \\
\hline $\begin{array}{l}\text { State } \\
\text { Privatized } \\
\text { New private }\end{array}$ & $\begin{array}{l}23 \\
43 \\
11\end{array}$ & $\begin{array}{c}19.27 / 12.97 \\
13.90 / 16.05 \\
2.51 / 4.83\end{array}$ & $\begin{array}{r}13.19 \text { / } 6.61 \\
5.35 / 8.40 \\
1.48 / 2.41\end{array}$ & $\begin{array}{r}23 \\
33 \\
7\end{array}$ & $\begin{array}{r}1232 / 797 \\
870 / 757 \\
123 / 164\end{array}$ & $\begin{array}{r}832 / 580 \\
413 \text { / } 335 \\
43 / 123\end{array}$ \\
\hline \multicolumn{7}{|l|}{ HUNGARY } \\
\hline $\begin{array}{l}\text { State } \\
\text { Privatized } \\
\text { Old private } \\
\text { New private }\end{array}$ & $\begin{array}{c}27 \\
46 \\
6 \\
15\end{array}$ & $\begin{array}{r}20.09 / 12.63 \\
12.94 / 10.51 \\
4.09 / 4.44 \\
1.61 / 2.43\end{array}$ & $\begin{array}{l}8.09 / 6.14 \\
5.77 / 5.13 \\
0.60 / 1.06 \\
0.55 / 1.56\end{array}$ & $\begin{array}{r}26 \\
43 \\
6 \\
16\end{array}$ & $\begin{array}{l}491 / 405 \\
559 / 446 \\
204 / 212 \\
113 / 158\end{array}$ & $\begin{array}{r}333 \text { / } 290 \\
320 \text { / } 270 \\
82 \text { / } 96 \\
83 \text { / } 133\end{array}$ \\
\hline \multicolumn{7}{|l|}{ POLAND } \\
\hline $\begin{array}{l}\text { State } \\
\text { Privatized } \\
\text { Old private } \\
\text { New private }\end{array}$ & $\begin{array}{c}43 \\
6 \\
13 \\
10\end{array}$ & $\begin{array}{r}9.55 / 8.36 \\
19.45 / 19.52 \\
8.37 / 12.23 \\
9.27 / 10.85\end{array}$ & $\begin{array}{r}5.27 / 4.64 \\
21.64 \text { / } 17.76 \\
1.47 / 10.31 \\
4.98 / 7.37\end{array}$ & $\begin{array}{c}43 \\
6 \\
16 \\
10\end{array}$ & $\begin{array}{r}726 \text { / } 534 \\
1107 / 861 \\
195 \text { / } 230 \\
205 \text { / } 196\end{array}$ & $\begin{array}{l}543 / 413 \\
786 / 752 \\
108 / 145 \\
120 / 187\end{array}$ \\
\hline
\end{tabular}

\section{B.4 SECTORAL DISTRIBUTION OF SAMPLE FIRMS( TWO-DIGIT SIC CODES)}

\begin{tabular}{|c|c|c|}
\hline \multirow{2}{*}{ Industry } & \multicolumn{2}{|c|}{ Number $(\%)$ of } \\
\hline & state firms & privatized firms \\
\hline Food\&beverages & $18(19 \%)$ & $27(29 \%)$ \\
\hline Clothing & $13(14 \%)$ & $18(19 \%)$ \\
\hline Furniture & $14(15 \%)$ & $9(10 \%)$ \\
\hline Textile & $9(10 \%)$ & $8(8 \%)$ \\
\hline Leather & $7(7 \%)$ & $7(7 \%)$ \\
\hline Chemicals & $13(14 \%)$ & $8(8 \%)$ \\
\hline Non-ferrous minerals & $15(16 \%)$ & $17(18 \%)$ \\
\hline Other & $4(5 \%)$ & $1(1 \%)$ \\
\hline
\end{tabular}

